\title{
Depositional evolution of an extinct sinter mound from source to outflow, El Tatio, Chile
}

\author{
Dylan T. Wilmeth ${ }^{\text {a,* }}$, Sami Nabhan a , Kimberly D. Myers a , Silvina Slagter ${ }^{\text {a,b }}$, Stefan V. Lalonde ${ }^{\text {, }}$ \\ Pierre Sansjofre ${ }^{\mathrm{d}}$, Martin Homann ${ }^{\mathrm{e}}$, Kurt O. Konhauser ${ }^{\mathrm{f}}$, Carolina Munoz-Saez ${ }^{\mathrm{g}}$, Mark A. van Zuilen ${ }^{\mathrm{a}}$ \\ a Equipe Géomicrobiologie, Université de Paris, Institut de Physique du Globe de Paris, CNRS, 75005 Paris, France \\ b Department of Earth and Planetary Sciences, Yale University, New Haven, CT 06511, USA \\ ' Laboratoire Géosciences Océan, Institut Universitaire Européen de la Mer, 29280 Plouzané, France \\ d Muséum National d'Histoire Naturelle, Sorbonne Université, CNRS UMR 7590, IMPMC, 75005 Paris, France \\ e Department of Earth Sciences, University College London, WC1E 6BT London, United Kingdom \\ ${ }^{\mathrm{f}}$ Department of Earth and Atmospheric Sciences, University of Alberta, T6G 2E3 Edmonton, Alberta, Canada \\ ${ }^{g}$ Department of Geology and Andean Geothermal Center of Excellence (CEGA), FCFM, Universidad de Chile, Plaza Ercilla 803, Santiago, Chile.
}

\section{A R T I C L E I N F O}

\section{Article history:}

Received 15 June 2020

Received in revised form 15 July 2020

Accepted 16 July 2020

Available online 22 July 2020

Editor: Dr. Brian Jones

\section{Keywords:}

Siliceous sinter

Hot springs

El Tatio

Microbialites

Microfossils

\begin{abstract}
A B S T R A C T
Siliceous sinter deposits from El Tatio, Chile, preserve a wide variety of depositional environments and biosignatures, from high-temperature $\left(\sim 85^{\circ} \mathrm{C}\right)$ vent-proximal facies to distal deposits dominated by silicified microbial mats. Four cores were drilled into an El Tatio sinter mound and associated distal apron to investigate changes in hydrothermal environments over geologic timescales. Sedimentary and geochemical analysis of multiple sinter cores records the initiation and accretion of diverse depositional features still observed today in El Tatio. Facies adjacent to hydrothermal vents are dominated by laminated sinter crusts on the steep margins of a high-temperature pool, with sparse microbial preservation. Outer margins of the same pool contain extensive sinter columns up to ten centimeters in length, precipitated during repeated cycles of pool overflow and subsequent evaporation. Low-relief hydrothermal pools also form minor deposits within distal debris aprons, and analogous pools are still active close to sampling locations. Debris aprons are dominated by palisade, tufted, and arborescent microbial fabrics, with distinct mat textures revealing well preserved microfossils. Surficial deposits in all cores feature detrital-rich and microbially-influenced sinters overlying higher-temperature facies, indicating a relative decrease in hydrothermal activity over time. Geochemical proxies for hydrothermal fluids and detrital input match depositional interpretations based on sedimentary structures. ${ }^{14} \mathrm{C}$ ages from core deposits extend the mound's history by 11,000 years, recording at least three thousand years of sinter deposition on top of glacial sandstones (13,337-10,232 y. cal. BP). Importantly, this work provides a detailed depositional model unavailable through surficial sedimentology alone.
\end{abstract}

(C) 2020 The Author(s). Published by Elsevier B.V. This is an open access article under the CC BY license (http:// creativecommons.org/licenses/by/4.0/).

\section{Introduction}

Siliceous sinter deposits form when amorphous silica (opal-A) precipitates in terrestrial hydrothermal environments, such as geysers and hot springs. Water temperatures in hot springs decrease from near-boiling vents to distal outflow channels $\left(<30^{\circ} \mathrm{C}\right)$, often within several meters. Thermal gradients along geothermal springs produce lateral variations in aqueous geochemistry, biological communities, and physical depositional processes. The complex relationships between these parameters produce an extraordinarily diverse range of microenvironments within localized areas. Silica precipitation within sinters preserves microscopic features in exquisite detail, especially microbial

\footnotetext{
* Corresponding author.

E-mail address: wilmeth@ipgp.fr (D.T. Wilmeth).
}

cells and their extracellular polymeric substances (EPS) (Walter, 1976a; Schultze-Lam et al., 1995; Cady and Farmer, 1996; Konhauser and Ferris, 1996; Jones et al., 1997, 1998, 2004, 2005; Konhauser et al., 2001, 2003; Handley et al., 2005; Campbell et al., 2015; Gong et al., 2019; Sriaporn et al., 2020). Hydrothermal siliceous sinters therefore have the potential to record fine-scale transitions in sedimentology, biology, and geochemistry over relatively short distances. Early sedimentary deposits ( $>3$ billion-years-old (Ga)) on Earth and Mars contain the oldest observed sinters (Ruff and Farmer, 2016; Djokic et al., 2017; Ruff et al., 2020). On Earth, such deposits include the earliest evidence for life in non-marine environments (Djokic et al., 2017), making work on modern hot springs highly relevant for investigating ancient sedimentology and biosignatures in paleo- and astrobiology.

Lateral gradients in sinter architecture are preserved in modern and ancient hydrothermal systems (Cady and Farmer, 1996; Walter et al., 
1996; Guidry and Chafetz, 2003a; Lowe and Braunstein, 2003; Hinman and Walter, 2005). Despite variations in local geochemistry and climate, consistent patterns of biogenic and abiogenic textures are present across multiple localities, forming a well-established model for sinter depositional facies. The stratigraphic evolution of hydrothermal sinters over geologic timeframes has also been studied in deposits of various ages (Trewin, 1993; Walter et al., 1996; Campbell et al., 2001), including drill cores through recently active localities (Jones et al., 1998; Guidry and Chafetz, 2003b; Lynne et al., 2008; Campbell et al., 2020). However, compared with clastic and carbonate environments, several aspects of sinter stratigraphy remain poorly constrained. For example, recent sinter cores only record cooler vent-distal environments such as outflow channels and debris aprons, with primary water temperatures interpreted around $30{ }^{\circ} \mathrm{C}$ (Jones et al., 1998; Guidry and Chafetz, 2003b; Lynne et al., 2008; Campbell et al., 2020). In contrast, only one study in Devonian strata interprets long-term stratigraphy of higher-temperature sinter facies $\left(>60^{\circ} \mathrm{C}\right)$ closer to vent sources (Walter et al., 1996). The study of vent-proximal sinters is especially relevant to the field of geobiology, as highertemperature zones are often inhabited by different microbial communities than cooler outflow deposits. Temperatures extremely close to vents in certain environments can be too hot for life, and distinguishing which sinters are actively mediated by microbes, passively preserving traces of life, or are completely abiogenic, has been a continuing topic of research for decades (Walter, 1976a, 1976b; Jones et al., 1997; Konhauser et al., 2001, 2003; Lowe and Braunstein, 2003; Handley and Campbell, 2011; Campbell et al., 2015).

Here, we present sedimentary, geochemical, and geochronological data from four cores drilled within an extinct sinter mound in El Tatio, Chile, including the first stratigraphic profiles of cores from ventproximal sinters. Facies changes and the preservation of biological communities were observed on various scales using stratigraphic logs, petrographic analyses, and scanning electron microscopy (SEM). Shifts in siliciclastic input and primary silica precipitation were studied using geochemical signatures of sinters and underlying sandstone. The detailed sedimentology and stratigraphy of multiple cores provides the basis for a depositional model of the sinter mound, spanning thousands of years in an arid, high elevation geothermal setting.

\section{Geological setting}

The El Tatio geothermal field is located in the Andes Mountains of northern Chile, $10 \mathrm{~km}$ west of the Chile-Bolivia border and $80 \mathrm{~km}$ north of San Pedro de Atacama (Fig. 1A). El Tatio contains the world's highest geyser field ( $4300 \mathrm{~m}$ a.s.l.), and the largest geyser field $\left(\sim 30 \mathrm{~km}^{2}\right)$ in the Southern Hemisphere (Zeil, 1959; Trujillo, 1969; Jones and Renaut, 1997; Glennon and Pfaff, 2003; Tassi et al., 2005; Munoz-Saez et al., 2018). The extreme altitude of El Tatio produces a different environment compared with many sinter locations. At 4300 m elevation, atmospheric pressure is $0.58 \mathrm{~atm}$, oxygen partial pressure is $0.12 \mathrm{~atm}$, and the boiling temperature of water is $86^{\circ} \mathrm{C}$. Daily temperatures have been measured between -5 and $25{ }^{\circ} \mathrm{C}$ during spring (Munoz-Saez et al., 2015), and drop to $-30{ }^{\circ} \mathrm{C}$ in winter (Fernandez-Turiel et al., 2005), resulting in frequent freeze-thaw cycles (Nicolau et al., 2014). Wind speeds also follow daily cycles, increasing to $7 \mathrm{~km} / \mathrm{h}$ several hours after sunrise (Slagter et al., 2019). El Tatio is located in the arid Chilean Altiplano, receiving a mean annual precipitation of $44 \mathrm{~mm} / \mathrm{y}$, with a maximum of $160 \mathrm{~mm} / \mathrm{yr}$ over the last 40 years (DGA, 2017). Ultraviolet radiation levels are also elevated at the extreme altitudes of El Tatio, with maximum UV-A and UV-B levels at 33 and $6 \mathrm{~W} / \mathrm{m}^{2}$, respectively (Phoenix et al., 2006). Many environmental factors at El Tatio are analogous to conditions modelled on early Earth and Mars, including high ultra-violet radiation and lower atmospheric pressure (Cockell, 2000; Som et al., 2012, 2016; Ruff and Farmer, 2016).

El Tatio occurs above the Altiplano-Puna Magma Body (Ward et al., 2014), which had an extensive explosive phase of eruption during the Miocene-Pleistocene (10-1 Ma) (De Silva, 1989; Leidig and Zandt,
2003; De Silva et al., 1994). Surficial hydrothermal activity in El Tatio primarily occurs in the hanging wall of a northeast trending half graben, which is filled with $\sim 1 \mathrm{~km}$ of sub-horizontal Miocene and Pliocene ignimbrites, tuffs, and lavas, and covered by Pleistocene/Holocene alluvial, glacial and sinter deposits (Healy and Hochstein, 1973; Lahsen and Trujillo, 1976). Hydrothermal waters are sourced from meteoric precipitation in the Bolivian Andes at $>5000 \mathrm{~m}$ elevation, $\sim 15 \mathrm{~km}$ east of El Tatio (e.g., Giggenbach, 1978; Cortecci et al., 2005; Munoz-Saez et al., 2018). Meteoric waters enter the subsurface and are heated by the AltiplanoPuna Magma Body as they flow westward (Healy and Hochstein, 1973); heated water interacts with the surrounding host rock to generate the fluids in the El Tatio reservoir, at an equilibrium temperature $>200{ }^{\circ} \mathrm{C}$ (e.g., Tassi et al., 2010; Munoz-Saez et al., 2018). The residence time of reservoir water is still unknown, but the lack of tritium sets a boundary $>60$ years (e.g., Cortecci et al., 2005; Munoz-Saez et al., 2018). Surface geothermal activity initiated within the peripheral margins of El Tatio in the late Pleistocene ( 27 ka, Munoz-Saez et al., 2020), with continuous activity during the Holocene ( $11 \mathrm{ka}$, Slagter et al., 2019).

\section{Methods}

\subsection{Sedimentology E' petrography}

Four cores $(A, C, D, E)$ were drilled along a vent-proximal $(A, C)$ to vent-distal terrace $(D, E)$ transect on an extinct sinter mound $\left(22^{\circ} 19^{\prime}\right.$ $40.41^{\prime \prime}$ S, $68^{\circ} 0^{\prime} 23.81^{\prime \prime}$ W, Figs. 1B-E, 2) in the Upper Basin of El Tatio, referred to in Slagter et al., 2019 as "Mound 502". The cores were drilled vertically, with the exception of core $\mathrm{D}$ which was drilled at $27^{\circ}$ from vertical, using a modified portable Shawtool Drill machine (diamond bit, $41 \mathrm{~mm}$ diameter) lubricated by cooled spring water from an adjacent spring. The cores were sawed in half using a diamond-edged tungsten carbide rotary saw to measure sedimentary features and stratigraphy; the working half of each core was used for petrographic and geochemical sample collection, while the corresponding archival halves were used for non-destructive analyses and stored at the $\mathrm{Na}$ tional Museum of Natural History of Paris. Thin-sections were made from 27 core samples (Institut Universitaire Européen de la Mer, Brest, France; Thin Section Lab, Toul, France), with standard petrographic techniques used to interpret primary micro-scale fabrics and secondary alteration. Detailed photomosaics of all thin-sections were created using a Zeiss Axio Zoom V16 Microscope equipped with Zeiss Zen imaging software (Institut de Biologie Paris-Seine).

\subsection{Scanning electron microscopy}

Scanning electron microscopy (SEM) was performed on rough, unpolished surfaces of 14 core samples fractured into 3-5 mm chunks. Samples were placed directly on aluminium stages with carbon glue, air-dried, and sputter-coated with gold before imaging. SEM images were obtained at the IPGP PARI analytical platform with a Zeiss EVO MA-10, at $15 \mathrm{kV}$ and 12-mm working distance on SE mode. $3.3{ }^{14} \mathrm{C}$ dating.

Five sinter samples (10 g each) were cut, cleaned, and ground down: two samples from Core $\mathrm{C}$ and four samples from Core $\mathrm{E}$ (Table 1, Fig. 2). The fine-grained samples were later treated with $1 \mathrm{~N} \mathrm{HCl}$ for $24 \mathrm{~h}$ and rinsed with ultrapure water. All samples were subsequently digested in $40 \%$ hydrofluoric acid (HF). The remaining carbonaceous (non-soluble) material was rinsed with ultrapure water and centrifuged. All samples, along with ${ }^{14} \mathrm{C}$-free wood and coal blanks, were dried, combusted, and cryogenically purified before being converted to graphite and measured by accelerator mass spectrometry at the UC Irvine Keck-CCAMS facility, using OX-I as the primary standard. The ages are reported in Table 1 as years before present (y. BP), where present is 1950 CE (Stuiver and Polach, 1977). Calibrated ages obtained on CALIB (http://calib.qub.ac.uk) using the SHCal13 dataset (Hogg et al., 2013) are also reported as mean ages according to a $2 \sigma$ confidence interval. Ages in the text are reported as calibrated years before present (y. cal. BP). $\delta^{13} \mathrm{C}$ values for samples 



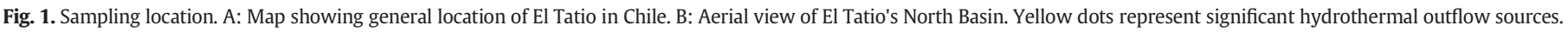

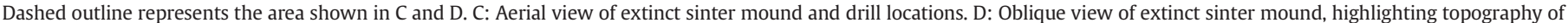
the sinter mound, interior pit, and drill locations. E: Profile of extinct sinter mound along transect in panel C.

were measured to a precision of $<0.1 \%$ orelative to PDB, using a Thermo Finnigan Delta Plus IRMS with Gas Bench input at UC Irvine (Table 1).

\subsection{Major and trace element analysis}

Powders from 76 core samples ( $150 \mathrm{mg}$ each) were analyzed at the Institut Universitaire Européen de la Mer (IUEM, Brest). All weighing and preparation of sample powders for solution mode ICP-MS and ICP-OES was carried out in a class 1000 clean lab at IUEM. PFA vials were acid washed internally and externally overnight in near-boiling, concentrated nitric acid $\left(\mathrm{HNO}_{3}\right)$, rinsed three times with $18.2 \mathrm{M} \Omega-\mathrm{cm}$ ultrapure water, then dried at room temperature and stored under clean conditions.

For major element analyses, 150-250 mg of powder was weighed into $30 \mathrm{~mL}$ PFA vials to which $3 \mathrm{~mL}$ of analytical-grade concentrated $\mathrm{HF}, 3 \mathrm{~mL}$ of concentrated $\mathrm{HNO}_{3}$, and $1 \mathrm{~mL}$ of concentrated $\mathrm{HCl}$ were added. Samples were digested completely overnight at $90{ }^{\circ} \mathrm{C}$, with kerogen as the only residue, and upon cooling in closed beakers, were diluted rapidly with $97 \mathrm{~mL}$ of concentrated $\mathrm{H}_{3} \mathrm{BO}_{3}$ solution to neutralize $\mathrm{HF}$ and prevent loss of $\mathrm{Si}$ as $\mathrm{SiF}_{4}$, following the method of Cotten et al. (1995). Diluted samples were analyzed for major elements using a Yvon Joriba Ultima 2 ICP-OES at the Pôle Spectrométrie Océan (PSO) at IUEM in Brest, France. Samples were calibrated against 8 similarly 


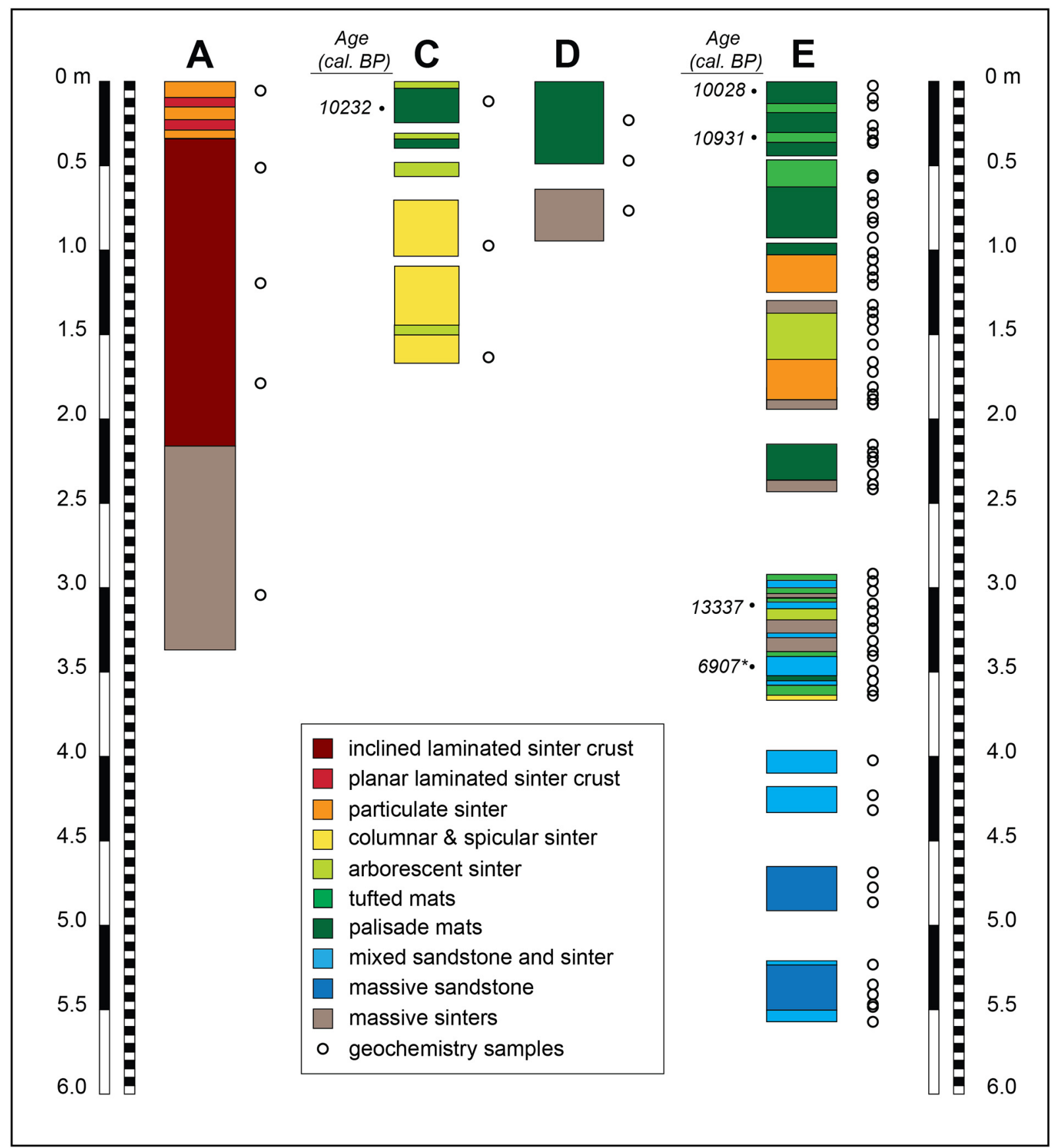

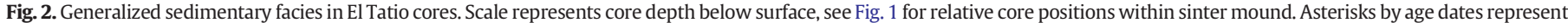
secondary influence on ${ }^{14} \mathrm{C}$ data. Table 1 lists specific depths for ${ }^{14} \mathrm{C}$ samples. Specific sample depths for all other chemistry samples are listed in the Supplementary Information.

Table 1

Radiocarbon ages from Mound 502. Ages referenced in-text represent the median probability in y. cal. BP, as shown in the final column.

\begin{tabular}{|c|c|c|c|c|c|c|c|c|c|c|c|c|c|}
\hline \multirow[t]{2}{*}{ Core } & \multirow{2}{*}{$\frac{\text { Depth }}{\mathrm{cm}}$} & \multirow{2}{*}{$\begin{array}{l}\text { Sample } \\
\text { Code }\end{array}$} & \multirow{2}{*}{$\frac{\text { Lab }}{\text { Code }}$} & \multirow{2}{*}{$\begin{array}{l}\text { Powder weight } \\
\mathrm{g}\end{array}$} & \multirow[t]{2}{*}{ Fraction modern } & \multirow[t]{2}{*}{ \pm} & \multirow{2}{*}{$\frac{\delta^{13} \mathrm{C}}{\%}$} & \multirow{2}{*}{ \pm} & \multirow{2}{*}{$\frac{{ }^{14} \mathrm{C} \text { age }}{\mathrm{y} \cdot \mathrm{BP}}$} & \multirow{2}{*}{ \pm} & \multicolumn{2}{|l|}{ cal age $^{a}$} & \multirow{2}{*}{$\begin{array}{l}\text { Median probability } \\
\text { y. cal. BP }\end{array}$} \\
\hline & & & & & & & & & & & y. cal. BP & & \\
\hline C & 12 & 18ETC12 & 218925 & 10.1 & 0.3213 & 0.0007 & -19.7 & 0.1 & 9,120 & 20 & 10,196 & 10,256 & 10,232 \\
\hline E & 6 & 18ETE6 & 218933 & 10.2 & 0.3294 & 0.0009 & -24.5 & 0.1 & 8,920 & 25 & 9,887 & 10,175 & 10,028 \\
\hline E & 33 & 18ETE33 & 218934 & 10.0 & 0.3017 & 0.0007 & -20.8 & 0.1 & 9,625 & 20 & 10,760 & 11,097 & 10,931 \\
\hline E & 310.5 & 18ETE310.5 & 218938 & 11.0 & 0.2380 & 0.0007 & -22.3 & 0.1 & 11,530 & 25 & 13,263 & 13,423 & 13,337 \\
\hline E & 347 & 18ETE347 & 218939 & 10.0 & 0.4684 & 0.0008 & -25.0 & 0.1 & 6,095 & 15 & 6,841 & 6,983 & 6,907 \\
\hline
\end{tabular}

\footnotetext{
a Using the SHCal13 dataset (Hogg et al., 2013). Calibrated ages are presented as mean ages with 2 sigma (95\%) confidence limits.
} 
prepared international geostandards (CB, BELC, JB, BEN, ACE, WSE, ME, and GSN) using the recommended values of Govindaraju (1995), with pure quartz as a high- $\mathrm{SiO}_{2}$ standard.

For trace element analyses, powders were completely digested with a three-step, heated $\mathrm{HF}-\mathrm{HNO}_{3}-\mathrm{HCl}$ attack, with kerogen as the only residue, using ultra-pure acids distilled in sub-boiling stills under clean lab conditions. First, approximately $100-150 \mathrm{mg}$ of powder was placed in an acid-cleaned PFA vial. $1.5 \mathrm{~mL}$ of $16 \mathrm{M} \mathrm{HNO}_{3}$ and $1.5 \mathrm{~mL}$ of $22 \mathrm{M} \mathrm{HF}$ were added. Samples were then capped and left to react overnight at $80^{\circ} \mathrm{C}$. Samples were then uncapped and left to evaporate to dryness for $24 \mathrm{~h} .3 \mathrm{~mL}$ of freshly mixed aqua regia was added to each residue, samples were capped and allowed to react for $6 \mathrm{~h}$ at room temperature to avoid excessive gas buildup. After $6 \mathrm{~h}$, caps were removed, and the sample was evaporated overnight at $80^{\circ} \mathrm{C}$ to dryness. Finally, $3 \mathrm{~mL}$ of $6 \mathrm{M} \mathrm{HCl}$ was added to each residue and samples were heated for $\sim 24$ h at $80{ }^{\circ} \mathrm{C}$. Prior to analysis, $100 \mathrm{~mL}$ of each sample was diluted to 5 $\mathrm{mL}$ with $2 \% \mathrm{HNO}_{3}$, and $1.5 \mathrm{~mL}$ of each sample was archived. International geostandards IF-G, BCR-2, and BHVO-2 were prepared in duplicate in the same batch and treated as unknowns to monitor precision.

Diluted samples were measured in solution mode on a Thermo Element2 HR-ICP-MS at the PSO. Samples were calibrated by gravimetrically-prepared multi-element standards at concentrations of $0.5,5$, and $50 \mathrm{ng} / \mathrm{g}$ that were measured repeatedly throughout the session. Additionally, a $5 \mathrm{ng} / \mathrm{g}$ In (Indium) standard was added to each sample, standard, and rinse, and was used to monitor signal stability and to correct for instrumental drift across the session. Each sample and standard were bracketed by a rinse for which data was also acquired to determine the method detection limit.

Rare earth element (REE) concentrations were normalized against background clastic deposition at Mound 502, as well as traditional standards such as chondritic meteorites and post-Archean Australian shale (PAAS). REE concentrations in Mound 502 clastic deposits were measured from a sinter-free massive sandstone sample from the lowest half-meter of Core E (Fig. 2). REE data shown and discussed below are clastic-normalized, for easier interpretation of clastic vs. hydrothermal influence in sinter deposits. Chondrite- and PAAS-normalized REE values are present in the Supplementary Information.

Eu anomalies were calculated using the clastic-normalized REE data to compare the relative influence of hydrothermal fluids between samples in relation to detrital input (Michard, 1989; Lewis et al., 1997; Feng et al., 2014). Eu anomalies represent enrichments or depletions of Eu compared with Sm and Gd within samples, and are typically calculated in a given sample using the equation:

Eu anomaly $=2 * \mathrm{Eu} /(\mathrm{Sm}+\mathrm{Gd})$

Anomaly values greater than 1 represent Eu enrichment, and are typically interpreted as evidence for higher hydrothermal influence (Michard, 1989; Lewis et al., 1997; Feng et al., 2014).

\section{Depositional facies}

Ten sedimentary facies were identified during core analysis, each representing a different depositional environment (Fig. 2, Table 2). All facies described have modern equivalents within active El Tatio hydrothermal systems. Fig. 2 illustrates the progression of sedimentary facies and interpreted environments over time, and Table 2 contains diagnostic features for each facies.

Mound 502 rises 2-3 m above surrounding topography, and is $20 \mathrm{~m}$ in diameter, with a roughly circular outline (Fig. 1C). Western margins are fairly steep, while eastern margins gradually slope into a debris apron. The mound's interior is dominated by a debris-filled pit $1.5 \mathrm{~m}$ deep and five meters wide which represents the inactive former vent, surrounded by a one-meter wide flat-topped sinter rim. As with exterior mound slopes, inner pit margins are steeper on the western face, surrounding the pit's deepest surface in the south-western corner (Fig. 1C, D).
Mound 502 is bordered to the north by a low-lying marsh with geothermal and meteoric water sources, bordered by vegetated hills further north and west (Fig. 1B). Relatively flat, barren plains border the mound to the south and east (Fig. 1B). While the mound itself contains minimal visible hydrothermal activity, adjacent plains within ten meters to the south and east contain several active pools and widespread fumaroles. Boiling pool margins contain small columnar and spicular sinters (see Section 4.4), but do not form mounds above the surrounding flat topography.

Core A (3.38 m long) was drilled within the eastern sinter rim, adjacent to the inner pit margin (Fig. 1C, D). Cores C (1.94 m long) and D (0.98 m long) were drilled $\sim 1.5 \mathrm{~m}$ below the top of Core A along the outer eastern and southern margins, respectively. Core D was drilled $27^{\circ}$ from vertical (Fig. 1E). Core E (5.57 m long) was drilled in a flat debris apron $15 \mathrm{~m}$ away from the sinter margin.

\subsection{Inclined laminated sinter crust}

Laminated sinter crusts are defined by dense, surface-normal fabrics of amorphous silica, forming mm-scale laminae of consistent thickness (Fig. 3). Similar deposits in Yellowstone siliceous sinters have been labeled "vent-proximal facies" and "laminated crusts" (Guidry and Chafetz, 2003a, 2003c), as well as "dendritic sinter facies" (Lowe and Braunstein, 2003). The term "dendritic" is avoided in this study to prevent confusion with branching arborescent sinter elsewhere in El Tatio cores (see Section 4.5).

Laminated crusts are divided into two separate facies in Mound 502 based on bed orientation and depositional interpretation: inclined crusts and planar crusts (Section 4.2). Inclined crusts are only observed in Core A, between 34 and $217 \mathrm{~cm}$ depth, with a shift in textural preservation at $164 \mathrm{~cm}$ depth (see below). The inclination of laminae and bedding varies between $45^{\circ}$ and nearly vertical, with most areas around 70 ${ }^{\circ} \mathrm{C}$ or higher inclination (Fig. 3). Well-preserved zones are composed of silica laminae 1-2 mm thick, alternating between pale surface-normal fabrics and thinner $(<1 \mathrm{~mm})$, darker layers of more massive silica (Fig. 3A-C). No microbial textures or cells are observed, and detrital grains are rare or absent.

Below $164 \mathrm{~cm}$ depth in Core A, inclined crusts are gray or light green and have little to no porosity. Detailed fabrics are only visible in thin sections, where individual laminae contain surface-normal clusters of amorphous silica, which flare and diverge away from bedding planes (Fig. 3D). Preservation varies between individual laminae, with more altered layers only exhibiting faint layering (Fig. 3D). Samples also contain dark, linear cross-cutting features occurring 1-3 cm apart (Fig. 3B). Cross-cutting textures disrupt and propagate through several centimeters of inclined crusts, independent of textural preservation.

Above $164 \mathrm{~cm}$, inclined crusts are more well-preserved, and surfacenormal fabrics become increasingly visible in hand samples (Fig. 3A-C). In the uppermost facies (34-51 cm depth), inclined crusts are white, extremely friable, and contain very few detrital grains (Fig. 3C). Inclination decreases upward from 70 to $45^{\circ}$, with rare cross-cutting textures present. In SEM images of the uppermost inclined facies, surface-normal fabrics are composed of elongated tubes of silica $\sim 50 \mu \mathrm{m}$ wide and up to 1 $\mathrm{mm}$ in length (Fig. 3E, F). Closer examination of individual tubes reveals irregularly porous cores with scalloped circular textures, surrounded by $\mu \mathrm{m}$-scale laminae around the outermost tube margins (Fig. 3F). Rare silicified filaments are also present within individual laminae, comprising less than $5 \%$ of inclined textures (Fig. 3G, H). Filaments are smaller than surrounding surface-normal tubes (10-20 $\mu \mathrm{m}$ wide, $<200 \mu \mathrm{m}$ long), and are not consistently oriented (Fig. 3G, H). Instead, filaments more closely resemble preserved cells in microbial facies (Figs. 8, 10, 11, see Sections 4.5-4.7).

Laminated sinter crusts are observed in subaqueous hydrothermal environments where silica precipitation typically outpaces microbial mat formation, such as vent-proximal pools (Guidry and Chafetz, 2003a; Lowe and Braunstein, 2003). SEM images most closely resemble 
Table 2

Sedimentary facies and depositional interpretations in Mound 502.

\begin{tabular}{|c|c|c|c|}
\hline Facies & Features & $\mathrm{T}\left({ }^{\circ} \mathrm{C}\right)$ & Environment \\
\hline $\begin{array}{l}\text { Inclined laminated } \\
\text { sinter crust }\end{array}$ & $\begin{array}{l}\text { Angled/near-vertical bedding, surface-normal textures, low detritus, sparse } \\
\text { microfossils }\end{array}$ & $>70{ }^{\circ} \mathrm{C}$ & Steep-walled hot pools \\
\hline $\begin{array}{l}\text { Planar laminated sinter } \\
\text { crust }\end{array}$ & Flat-bedded, surface-normal textures, low detritus, no microfossils & $>70^{\circ} \mathrm{C}$ & Flat-bottomed hot pools \\
\hline Particulate sinter & Diffuse wavy laminae of silica spheres, rare detrital layers, no microfossils & $>70{ }^{\circ} \mathrm{C}$ & Flat-bottomed hot pools \\
\hline $\begin{array}{l}\text { Columnar \& spicular } \\
\text { sinter }\end{array}$ & $\begin{array}{l}\text { Clustered elongate silica protrusions, convex lamination, low detritus, no } \\
\text { microfossils }\end{array}$ & $\sim 70{ }^{\circ} \mathrm{C}$ & Splash/spray zones around geysers and pools \\
\hline Arborescent sinter & Vertically branching structures, variable detritus, microfossils present & $\begin{array}{l}15-80 \\
{ }^{\circ} \mathrm{C}\end{array}$ & $\begin{array}{l}\text { Outflow channels, higher discharge than palisade or } \\
\text { tufted mat facies }\end{array}$ \\
\hline Fenestral palisade sinter & $\begin{array}{l}\text { Highly-porous, abundant microfossils alternately oriented surface-normal and } \\
\text { parallel, low detritus }\end{array}$ & $\begin{array}{l}40-45 \\
{ }^{\circ} \mathrm{C}\end{array}$ & $\begin{array}{l}\text { Low-temperature microbial mats in distal outflow } \\
\text { aprons }\end{array}$ \\
\hline Tufted mat sinter & $\begin{array}{l}\text { Porous laminae forming sharp peaks and cones, abundant microfossils, low } \\
\text { detritus }\end{array}$ & $\begin{array}{l}45-60 \\
{ }^{\circ} \mathrm{C}\end{array}$ & $\begin{array}{l}\text { Mid-temperature microbial mats in distal outflow } \\
\text { aprons }\end{array}$ \\
\hline Massive sinter & $\begin{array}{l}\text { Featureless in hand sample, petrography, and SEM, fractured with secondary } \\
\text { minerals }\end{array}$ & $\begin{array}{l}>70 \\
{ }^{\circ} \mathrm{C} ?\end{array}$ & Subsurface alteration \\
\hline $\begin{array}{l}\text { Laminated sinter \& } \\
\text { sandstone }\end{array}$ & Alternating bedded sandstone and laminated sinter & $<35^{\circ} \mathrm{C}$ & Distal outflow channels, silica-saturated \\
\hline Massive sandstone & No bedding, no sinter layers, grain-supported & $<20^{\circ} \mathrm{C}$ & $\begin{array}{l}\text { Distal outflow channels, little to no hydrothermal } \\
\text { influence }\end{array}$ \\
\hline
\end{tabular}

"shrub columns" with abundant porous silica structures described by Jones and Renaut (2003) from vent-proximal deposits in New Zealand. Internal porosity within branches of shrub columns are attributed to secondary dissolution, which can replace microbial cells or abiogenic mineral dendrites (Jones and Renaut, 2003). While porous surface-normal textures are ambiguously biogenic, the occasional presence of filamentous microfossils indicates that microbial communities were present.

The high angle of lamination over nearly $2 \mathrm{~m}$ suggests extensive precipitation on steep surfaces, most likely the inner subaqueous surfaces of a large high-temperature pool. The interpretation fits with Mound 502's current near-vent architecture, which consists of a 5-meter-wide steep-sided pit. The darker surface-normal lineations which disrupt laminae are potentially the propagations of corrugated or "rilled" bedforms commonly seen on vent walls (Braunstein and Lowe, 2001; Guidry and Chafetz, 2003a; Lowe and Braunstein, 2003). Therefore, the inclined fibrous facies in Core A are interpreted as the margins of a steep-walled pool immediately above a hydrothermal vent, most likely above $70{ }^{\circ} \mathrm{C}$.

\subsection{Planar laminated sinter crusts}

Planar laminated crusts contain thin layers of surface-normal silica fabrics (Fig. 4), similar to inclined sinter crusts (see Section 4.1), but exhibit consistently horizontal bedding. Planar crusts are only present in Core A from 11 to $34 \mathrm{~cm}$ depth, immediately above inclined crust facies. Planar and inclined crusts are separated from each other by a sharp unconformity. As with inclined crusts, laminae in planar facies are 1-2 mm thick, containing pale surface-normal fabrics separated by thin, darker massive laminae (Fig. 4A). Boundaries between light and dark layers are more distinct in planar than inclined fibrous facies. Detrital sinter pieces and siliciclastic material are rare, but more abundant in darker laminae (Fig. 4A). Porosity in both light and dark layers is low on mmto cm-scales.

SEM imaging of planar sinter crusts reveals two distinct styles of preservation (Fig. 4B,C). Light laminae are composed of adjacent vertical chains of silica spherules $\sim 100 \mu \mathrm{m}$ in diameter (Fig. 4B). Vertical textures in light laminae superficially resemble surface-normal textures within inclined sinters, but notably lack porous, scalloped cores (Figs. 3E, F, 4B). By contrast, dark laminae contain linear highly-porous zones $20 \mu \mathrm{m}$ wide, surrounded by rinds of amorphous silica (Fig. 4C). Pores in planar crusts lack consistent orientation, and are typically smaller and less interconnected than in inclined facies.
As with inclined sinter crusts, planar facies are observed within vent-proximal high-temperature deposits (Guidry and Chafetz, 2003a; Lowe and Braunstein, 2003). In Mound 502, planar laminated crusts are only observed within the flat-topped inner rim which lines the inner pit (Fig. 1D). While inclined crusts were most likely deposited on the steep subaqueous margins of the main inner pit, planar crusts potentially represent adjacent, shallower flat-bottomed pools.

Lowe and Braunstein, 2003 described scattered microfossil filaments in Yellowstone sinter crusts ("dendritic sinter facies"), though many more samples contained no trace of microbial presence. Similarly, planar crusts in El Tatio cores contain no definitive microfossils, instead sharing similarities with ambiguously biogenic "shrub columns" described by Jones and Renaut, 2003. The lack of biosignatures does not preclude a microbial presence in planar sinter crusts, but supports a silica precipitation patterns less conducive to microfossil preservation (Walter, 1976b; Lowe and Braunstein, 2003; Hinman and Walter, 2005).

\subsection{Particulate sinter}

Particulate sinters are defined as beds of "botryoidal grains and chains" over $5 \mu \mathrm{m}$ in diameter, frequently associated with detrital grains (Braunstein and Lowe, 2001; Lowe and Braunstein, 2003; WattsHenwood et al., 2017). Particulate sinter facies occur at the top of Core A, and in two zones within Core E (103-125 cm, 165-195 cm depth). Particulate beds are typically gray with brown detrital material (Fig. 5A), and are closely associated with laminated sinter crusts, arborescent sinters (see Section 4.5), and massive sinters (see Section 4.8).

Particulate sinters are defined by diffuse planar to wavy laminae between 1 and 5 mm thick, comprised of rounded 50-100 $\mu$ m-wide agglomerates of opal spherules surrounded by pore space (Fig. 5B-E). Well-preserved hand samples of particulate facies show similar textures to associated thin sections (Fig. 5A), though many others are difficult to discern from massive sinter facies prior to microscopic analysis (see Section 4.8). Detrital material is abundant in specific layers as individual sand grains (Fig. 5C). No microfossils or preserved microbial mat textures are visible using petrographic or scanning electron microscopy.

Particulate facies are interpreted as high-temperature deposits along the bases of non-boiling hydrothermal pools, which occur both proximal and distal to vent sources. Spherical silica particles precipitate onto various substrates such as microbial cells and wind-blown detrital sediments, forming a sticky, laminar ooze comprised of amorphous, wetted silica and thin biofilms (Rimstidt and Cole, 1983; Lowe and Braunstein, 2003; Braunstein and Lowe, 2001; Watts-Henwood et al., 2017). Microbial cells can form a major component of particulate 

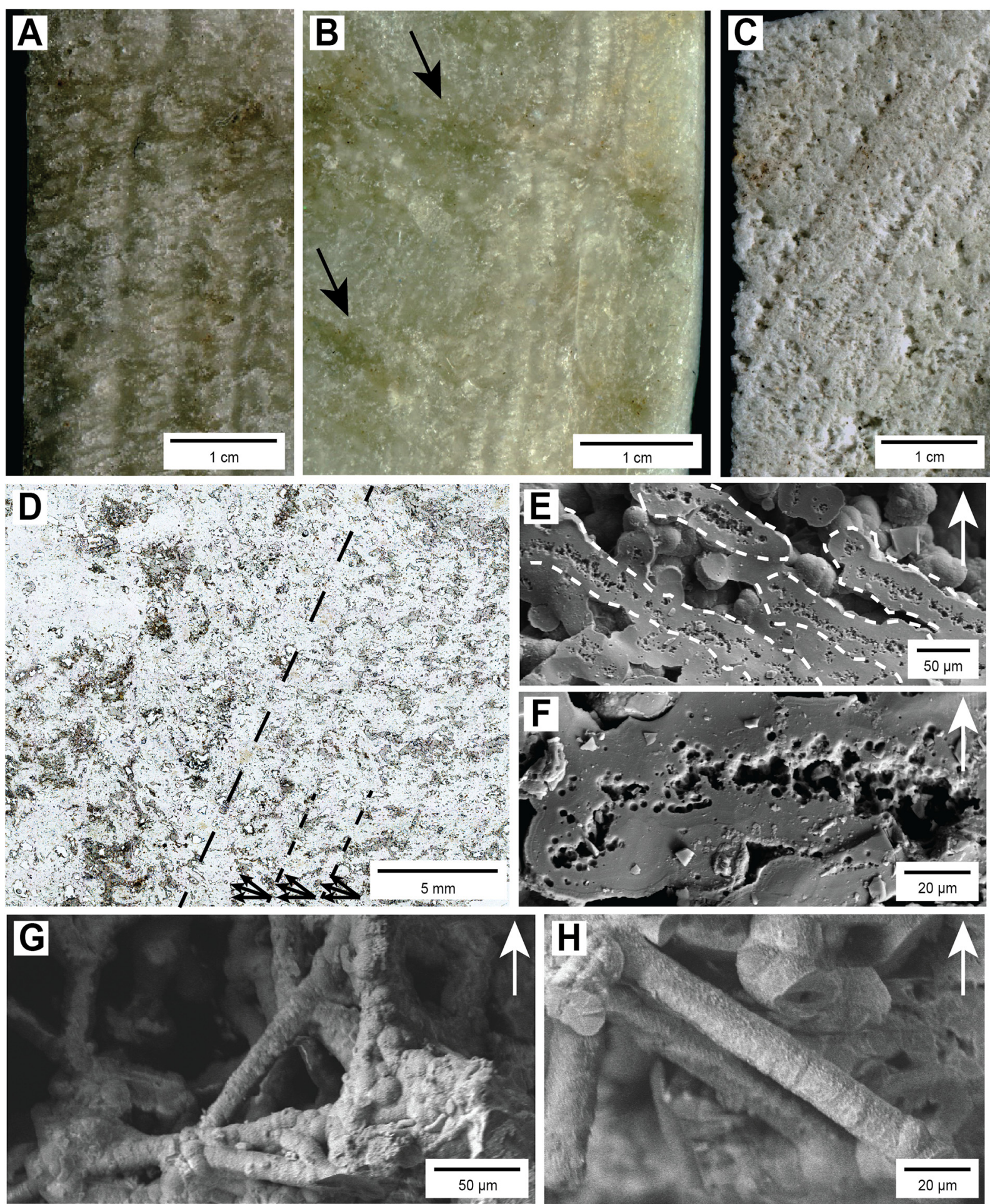

. 3. Inclined sinter crust. A, B and C are hand specimen photogtaphs. A, B: Nearly vertical sinter crusts in Core A at $1.4 \mathrm{~m}$ (A) and $1.6 \mathrm{~m}$ depth (B). Arrows in B highlight darker surface-

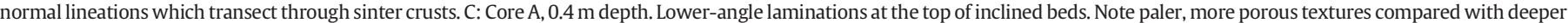

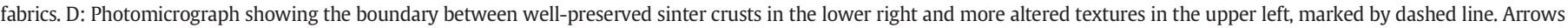

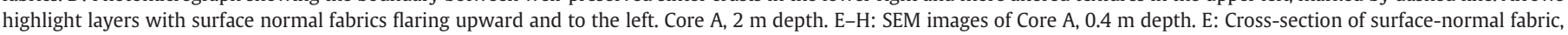

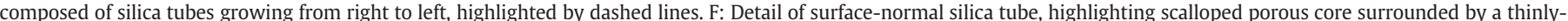

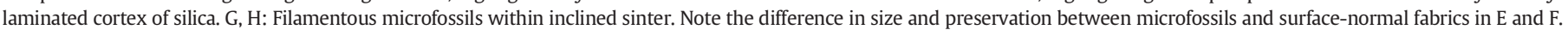

sinters, preserving silicified cells or cell fragments of microbes from various temperature regimes (Jones and Renaut, 1996; Braunstein and Lowe, 2001). Sediments are agitated by wind and hydrothermal currents, forming sinuous, ripple-like bedforms on pool floors (Lowe and Braunstein, 2003; Watts-Henwood et al., 2017). Similar textures are observed in extinct sinter mounds elsewhere in El Tatio, bearing irregular surfaces of low-relief ridges (Sanchez-Garcia et al., 2019). Modern high-temperature pools are present within debris aprons several meters downhill from Core E, providing a useful analogue for distal pool environments indicated by particulate facies. 

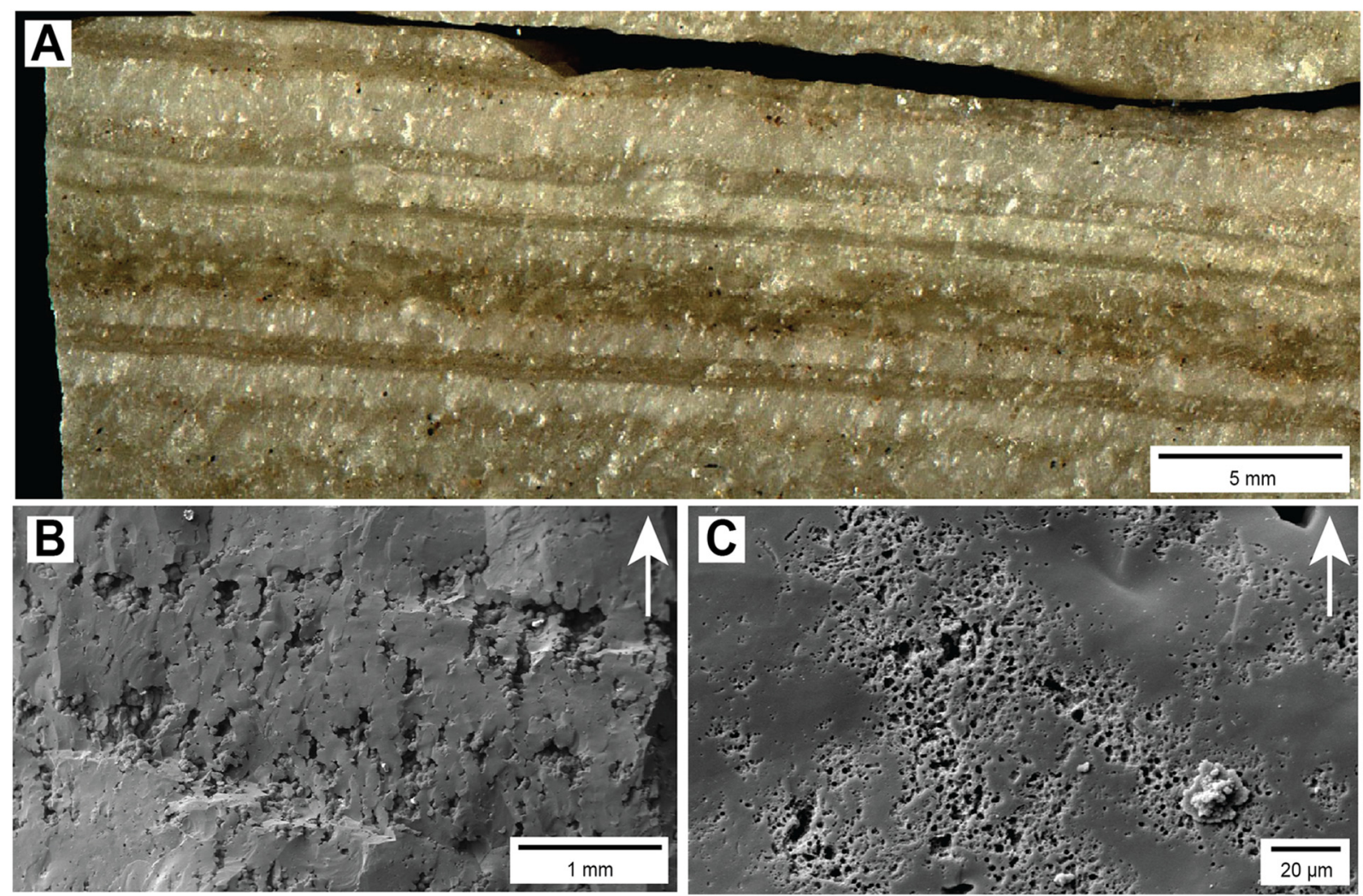

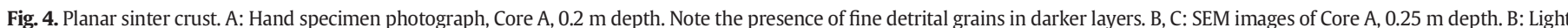
layer, comprised of vertical chains of silica spheres separated by interstitial pore space. C: Dark layer, highlighting porous zones surrounded by massive silica rinds.

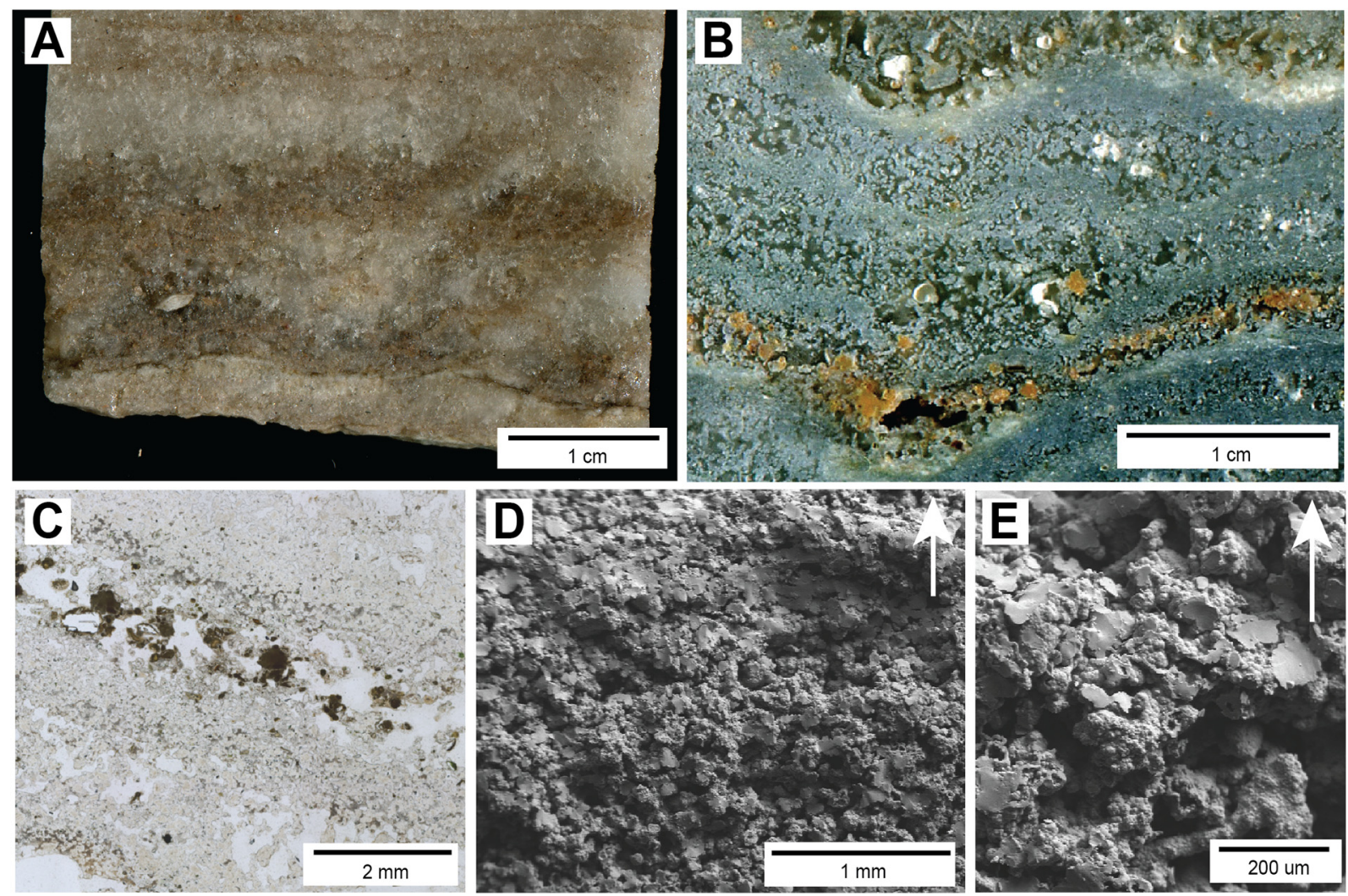

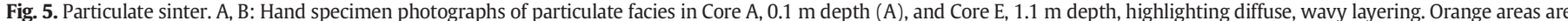

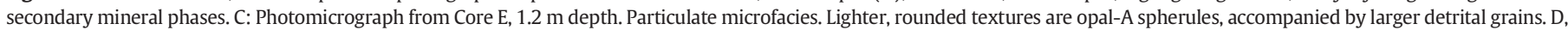
E: SEM images from Core E, $1.2 \mathrm{~m}$ depth, showing a cross-section of particulate sinter layers. Note the absence of microbial filaments or well-defined laminae. 


\subsection{Columnar and spicular sinter}

Cores $\mathrm{C}$ and $\mathrm{E}$ contain several distinct facies dominated by clusters of elongate sinter protrusions with convex laminae, which can be classified as columns and spicules (Figs. 6, 7). Columns are between 0.1 and $1 \mathrm{~cm}$ wide, and can exceed $5 \mathrm{~cm}$ in length (Walter, 1976b). Spicules are less than $1 \mathrm{~mm}$ in diameter, reaching up to $1 \mathrm{~cm}$ long (Walter, 1976b). The internal structure of spicules and columns are nearly identical, with definitions for each based on size (Walter, 1976b), though terminology varies slightly between studies (Jones and Renaut, 1997, 2003, 2006; Braunstein and Lowe, 2001).

Columnar sinter is most prevalent in Core C, from 70 to $167.5 \mathrm{~cm}$. Individual columns are $0.5-1 \mathrm{~cm}$ wide, and $1-5.5 \mathrm{~cm}$ long (Fig. 6C-E). Core $\mathrm{C}$ often truncates column lengths, but surface exposures of columnar facies verify the observed size ranges (Fig. 6A, B). In transverse crosssection, columns are typically circular to oval in shape (Fig. 6E). Columns
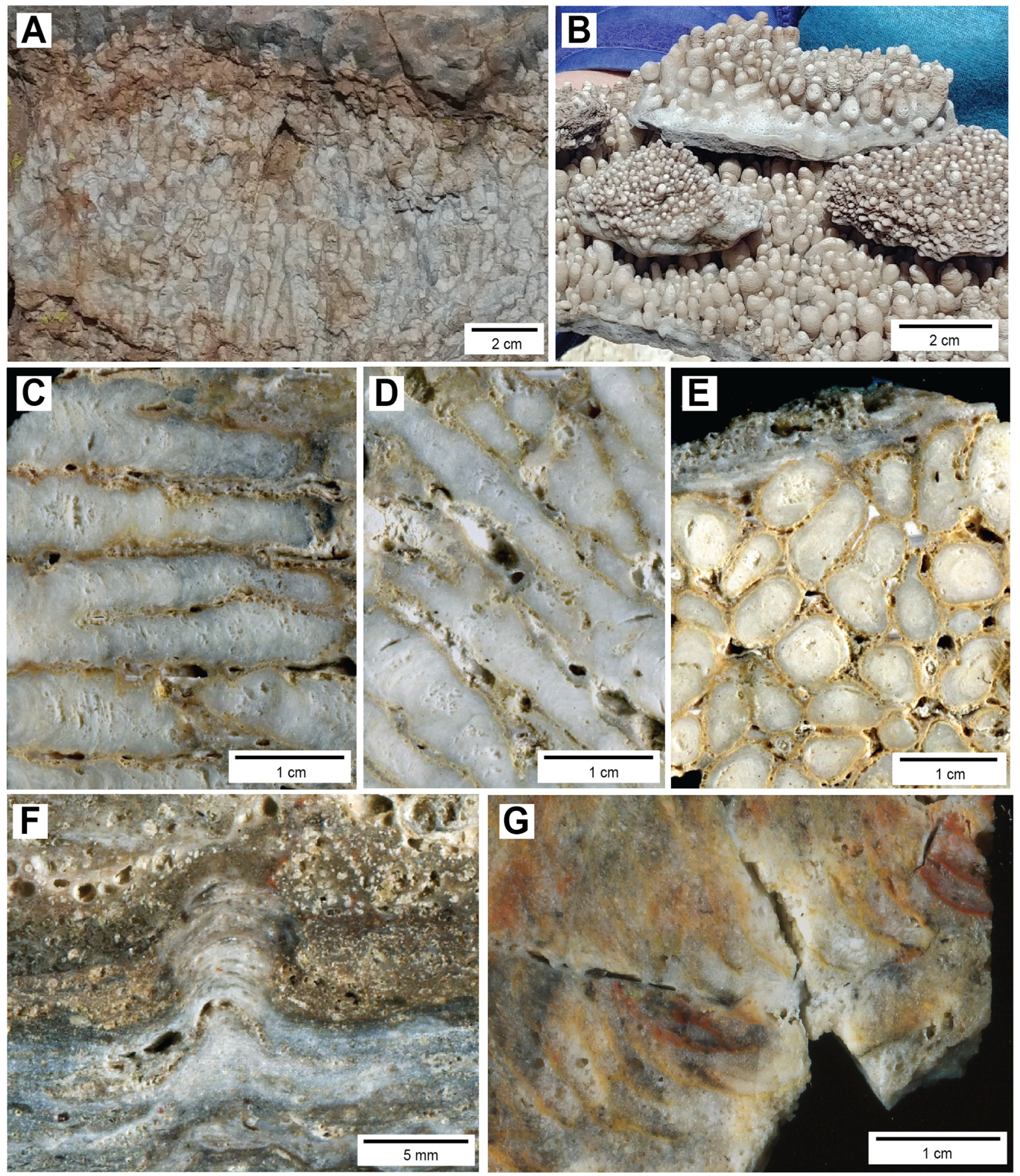

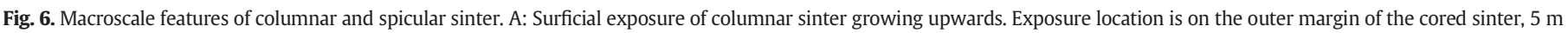

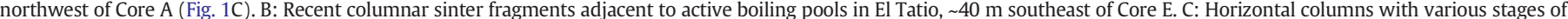

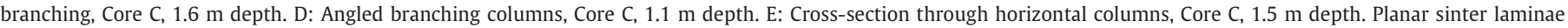

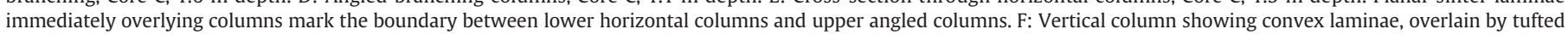
microbial sinter. Core E, $3.65 \mathrm{~m}$ depth. G: Curved spicules. Note the size difference between spicules and columns. Core C, $1.7 \mathrm{~m}$ depth. 

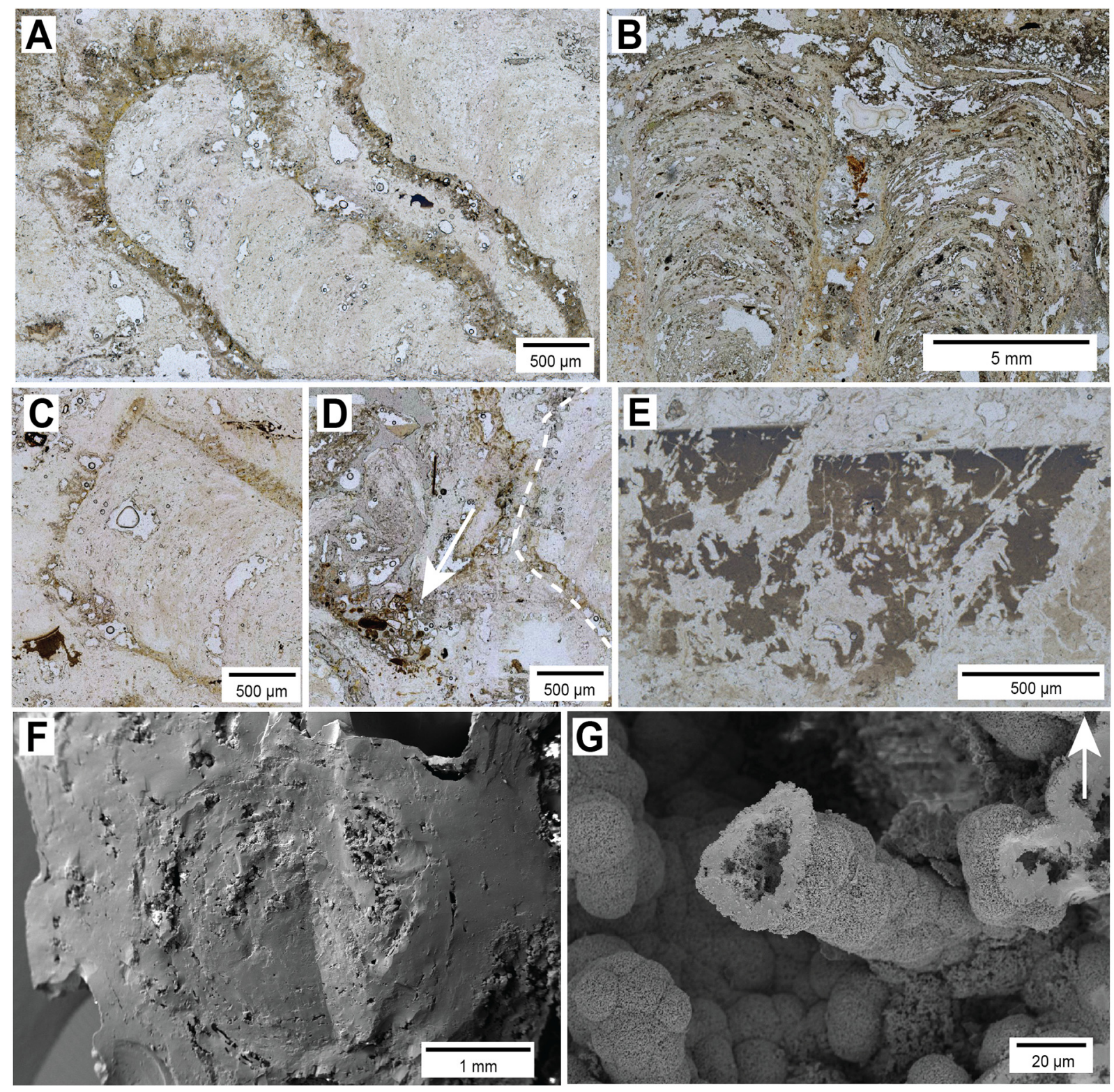

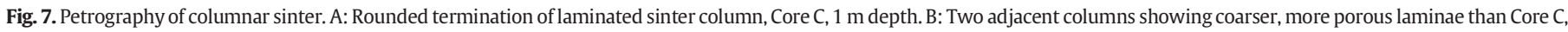

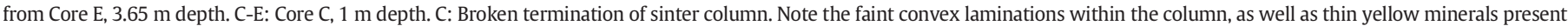

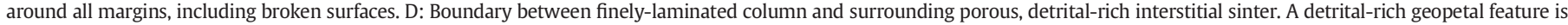

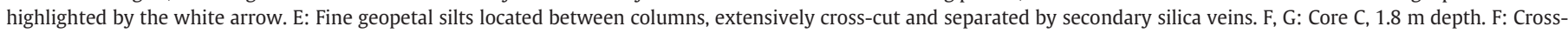

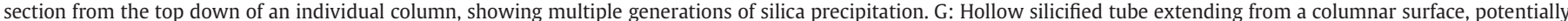
representing a rare preserved microfossil.

frequently exhibit branching morphologies, with individual branches reaching no more than $30^{\circ}$ of inclination from parent columns (Fig. 6C, D). The only change in column morphology occurs at $123.5 \mathrm{~cm}$ in Core C, where column orientation switches from horizontal to $60^{\circ}$ inclination. The change in angle occurs above an unconformity with planar laminated sinter (Fig. 6E).

Sinter columns in Core $\mathrm{C}$ are internally laminated, with laminations visible in longitudinal and transverse cross-sections (Figs. 6, 7). Laminae are convex in the direction of growth, either upwards in angled columns, or laterally in horizontal columns (Figs. 6C, D, 7A, C, D). The synoptic relief of individual layers within columns is relatively low, between 0.5 and $2.0 \mathrm{~mm}$ (Fig. 7A, C, D). Layers have low porosity, with sub-mm pores scattered throughout columns. SEM imaging also reveal column layers (Fig. 7F), with the rare presence of hollow silica tubes on the outer surfaces of columns (Fig. 7G). Interstitial gaps between columns are porous, with coarse or fine sediments on the bottom of pores serving as geopetal, or way-up, indicators (Fig. 7D, E). Fine geopetal sediments are often cross-cut with secondary silica veins (Fig. 7E). Other mineral phases include rims of yellow and brown oxidized crusts pervasively surrounding columnar edges (Fig. 7A, C, D). The presence of crusts on the ends of broken columns indicates secondary precipitation after initial column growth (Fig. 7C).

Columnar sinter is also present at $364 \mathrm{~cm}$ depth in Core E (Figs. 6F, $7 \mathrm{~B})$, within a $3 \mathrm{~cm}$ thick bed. Core E columns are vertical features $\sim 0.5$ $\mathrm{cm}$ in width and $1 \mathrm{~cm}$ in height, occurring in isolated clusters of one to three structures. Internal morphology closely resembles Core C columns, bearing convex-upwards laminae with $0.5 \mathrm{~mm}$ relief (Figs. 6F, 7B). Laminae in Core E columns are thicker than Core C (0.25-0.5 $\mathrm{mm}$ ), and contain higher amounts of detrital material Lower columnar margins have minor yellow mineral crusts, lacking dendritic textures 
observed in Core C. Columns are immediately overlain by tufted microbial sinters, but no evidence of significant microbial communities is present at the time of column deposition.

Spicular sinter occurs in a $5 \mathrm{~cm}$ thick bed immediately below columnar sinters in Core C, at $175 \mathrm{~cm}$ depth. Spicules are $1 \mathrm{~mm}$ wide and up to $1 \mathrm{~cm}$ long, with individual structures curving upwards from 30 to $70^{\circ}$ inclination (Fig. 6G). As with Core C columnar sinters, spicules are tightly packed and bordered by yellow and red mineral crusts. Laminae are not observed in spicule cross-sections. The spicule layer is immediately and unconformably overlain by horizontal columnar sinters.

Columnar and spicular sinters are commonly observed around boiling pools and geysers, in zones which exhibit frequent wetting and drying (Walter, 1976b; Jones et al., 1997, 1998; Jones and Renaut, 1997, 2003, 2006; Braunstein and Lowe, 2001; Guidry and Chafetz, 2003a; Lowe and Braunstein, 2003; Boudreau and Lynne, 2012). Splashes and surges of hot, silica -rich water evaporate on nearby surfaces, precipitating opal-A. Over time, silica precipitation produces micro-scale topography that progresses into columnar morphologies, with capillary motion of water within columns providing silica over time (Walter, 1972, 1976b; Braunstein and Lowe, 2001; Jones and Renaut, 1997, 2003, 2006; Mountain et al., 2003). Splash zones close to pools and vents form spicular textures, while larger columns occur further away in surge and overflow environments (Walter, 1972, 1976b; Braunstein and Lowe, 2001). The upward increasing angle of columnar growth in Core $\mathrm{C}$ is likely due to local topography, with horizontal columns growing on nearly-vertical mound faces, and increasing angles of growth on progressively flatter surfaces closer to the tops of sinter rims. Incipient growth of vertical columns in El Tatio occurs around modern boiling pools several meters south of Core E (Fig. 6B). The modern pool-margin textures are nearly identical in size and orientation to Core E columns. Therefore, columnar sinters from Cores $\mathrm{C}$ and $\mathrm{E}$ are interpreted as silica precipitates that formed in the former splash and surge zones of boiling pools.

Columnar sinters frequently preserve microbial communities, both within columnar laminae and interstitial spaces between columns (Cady and Farmer, 1996; Jones et al., 1997, 1998; Guidry and Chafetz, 2003a, 2003b, 2003c; Jones and Renaut, 2003, 2006; Handley et al., 2005 , 2008). In other columnar sinter locations, biosignatures are less apparent (Walter, 1976b; Braunstein and Lowe, 2001; Lowe and Braunstein, 2003). Most columnar facies are interpreted as forming via biogenic and abiogenic silicification, with capillary forces, surge events, and precipitation within microbial communities dominating at different points in time (Jones et al., 1997; Jones and Renaut, 2003, 2006). In El Tatio cores, microbial textures in columnar sinter are obscured by diagenesis, with only isolated, putative microfossils within inter-columnar spaces (Fig. 7G). The columnar sinters examined are conservatively interpreted as forming through capillary forces after periodic surge events, with microbial communities likely present in cooler, moist areas between columns.

\subsection{Arborescent sinter}

Arborescent sinter is defined in this study as horizontal beds composed of surface-normal, extensively branching siliceous textures up to $1 \mathrm{~cm}$ in height (Fig. 8). The same textures are nearly identical to "siliceous shrubs" described in detail by Guidry and Chafetz, 2003c. However, the term "shrub" has been used to describe various different sinter textures such as laminated sinter crusts ("dendritic sinter facies" in Lowe and Braunstein, 2003), microbial palisade fabrics (Cady and Farmer, 1996; Walter et al., 1998; Campbell et al., 2001; see Section 4.6), and geyser-associated facies (Jones and Renaut, 2003). Similarly, the term "dendritic" is commonly applied to branching amorphous or mineral phases, and has been used in various sinter fabrics, such as laminated crusts, spicules, and microbial mats (Jones and Renaut, 2003; Lowe and Braunstein, 2003; Hinman and Walter, 2005), as well as phases other than amorphous silica, including quartz, calcite, and manganese (Bargar and Beeson, 1981; Jones et al., 1998; Walter et al., 1998; Guidry and Chafetz, 2003b). By contrast, the term "arborescent" is only applied to siliceous shrubs as described in Guidry \& Chafetz, 2003a \& c, the previously published descriptions which most closely resemble the El Tatio sinter facies presented here.

Various horizons in Cores $\mathrm{C}$ and $\mathrm{E}$ (Fig. 2) contain arborescent sinter. In Core C (0-3, 30-34 cm depth) and deeper in Core E (310-320 cm depth), arborescent sinters form minor units of $1 \mathrm{~cm}$-thick beds interspersed between sandstones, microbial, and massive sinter facies (Fig. 8A-B). Arborescent layers higher in Core $\mathrm{E}$ form persistent beds between 142 and $187 \mathrm{~cm}$ (Fig. 8C) and are closely associated with particulate sinters (see Section 4.3). In Cores C and E, arborescent sinter contains individual branching structures that reach up to $1 \mathrm{~cm}$ high, with individual branches less than $1 \mathrm{~mm}$ in diameter (Fig. 8A-C). Arborescent zones form highly porous areas compared with over- and underlying facies, and are often separated by $\mathrm{mm}$-scale interstitial layers of less porous sinter (Fig. 8B, C). Interstitial sinter layers also contain higher abundances of detrital grains, often appearing darker in colour than white or light gray arborescent layers (Fig. 8B, C).

Petrographic analysis of arborescent structures reveals branching chains of amalgamated siliceous spheres up to $100 \mu \mathrm{m}$ in diameter (Fig. 8D). Individual arborescent features and branches are often separated by pore space, with more extensive silica precipitation resulting in smaller interstitial voids. SEM images show similar branching textures as observed in thin sections (Fig. $8 \mathrm{E}$ ), as well as the presence of silicified microfossils and higher quantities of detrital material at the top of individual arborescent beds (Fig. 8E-G). Microbial filaments are 10-20 $\mu \mathrm{m}$ wide and over $200 \mu \mathrm{m}$ long, resembling cells preserved in palisade mat and tufted mat facies (see Sections 4.6 \& 4.7). Microfossils are found in clusters within and around larger branching features at lower densities than other microbial facies in El Tatio cores (Figs. 10, 11).

In active hydrothermal systems, arborescent sinters form within discharge channels as hydrothermal waters flow away from vent sources (Guidry and Chafetz, 2003a, 2003c). Within such depositional environments, arborescent facies appear to be temperature-independent, forming in subaqueous zones between 15 and $80{ }^{\circ} \mathrm{C}$ (Guidry and Chafetz, 2003c). Microbial communities preserved in El Tatio arborescent facies corroborate findings from similar Yellowstone sinters (Guidry and Chafetz, 2003c). Guidry and Chafetz, 2003c noted the presence of branching "siliceous shrubs" in discharge channels with higher outflow volume, while laminated microbial mats were abundant in lower outflow zones. Based on these observations, arborescent sinters in El Tatio cores are interpreted as silicified microbial communities in high-volume discharge channels, both in vent-proximal zones and distal aprons.

\subsection{Fenestral palisade sinter}

Palisade sinters are defined by silicified filamentous microfossils alternating between layers of surface-normal and surface-parallel orientation (Cady and Farmer, 1996; Walter et al., 1996; Campbell et al., 2001; Gong et al., 2019). Similar textures are observed, but not specifically labeled as palisades, in hydrothermal stromatolites (Jones et al., 1997, 1998, 2005; Konhauser et al., 2004; Berelson et al., 2011), with a variety of terms applied to microfossil orientation (erect vs. prostrate, U- vs. P-laminae, and upright vs. flat-lying). Palisades occur in the top $50 \mathrm{~cm}$ of Cores C, D, and E, and between 215 and $244 \mathrm{~cm}$ depth in Core E. Most El Tatio core palisades contain high abundances of fenestrae (Figs. 9, 10), defined as primary pore spaces preserved within microbial textures (Tebbutt et al., 1965; Mata et al., 2012).

Fenestral porosity alternates between individual laminae, resulting in light-dark layering within hand samples and thin sections. Lighter, more porous laminae are 2-5 mm thick, while darker laminae are less than 2 $\mathrm{mm}$ thick and contain fewer fenestrae. Detrital grains are present but not abundant throughout light and dark palisade laminae (Fig. 9E, G). Both styles of lamination contain filamentous microfabrics visible in thin-section and SEM imaging (Figs. 9D-G, 10A-E). Filaments in lessporous laminae are oriented parallel to bedding planes. In contrast, 

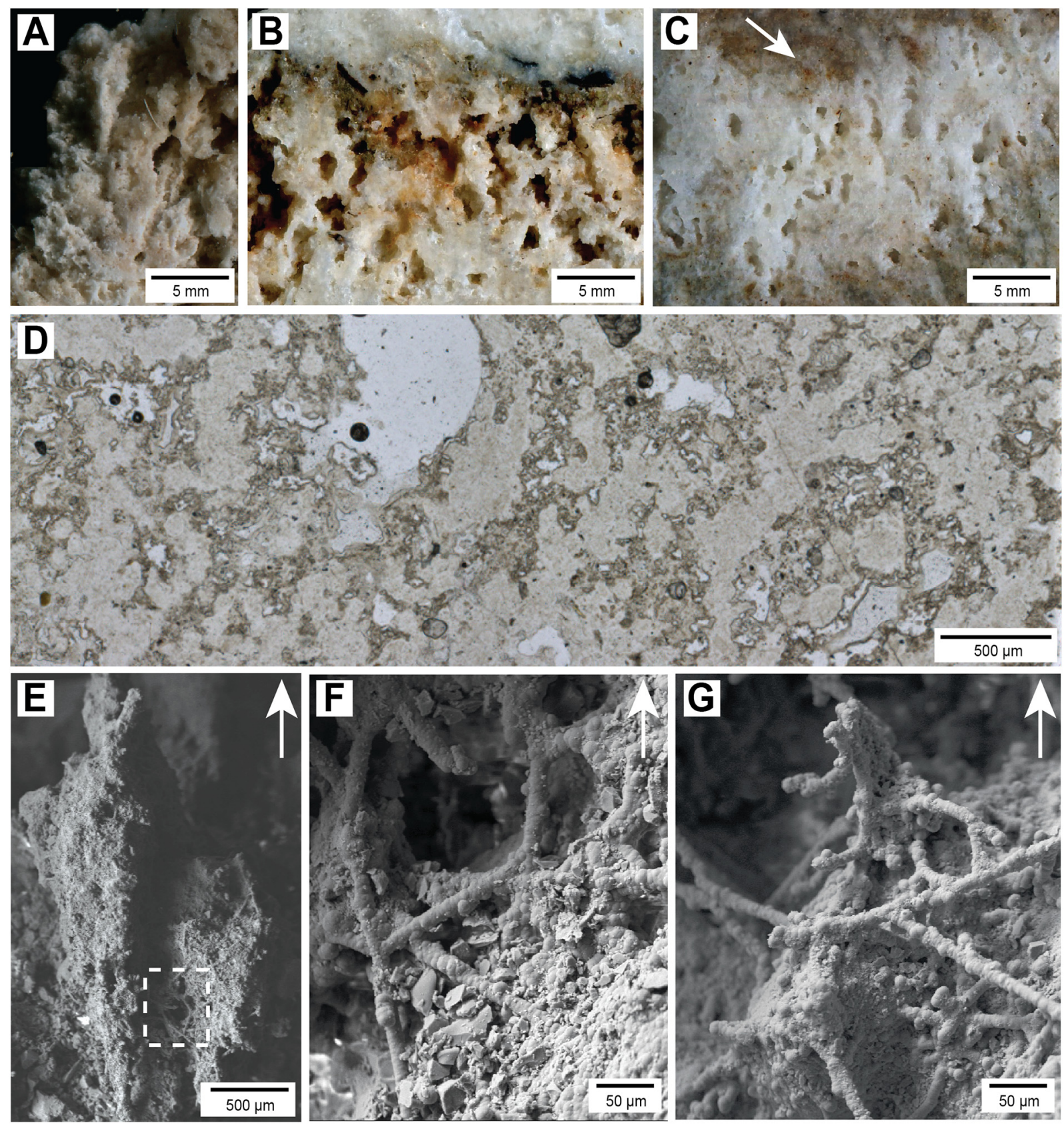

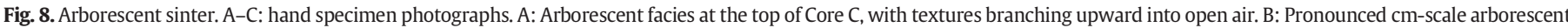

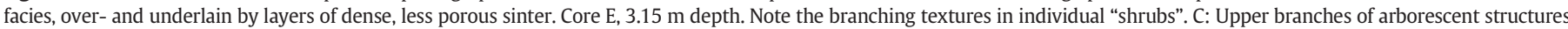

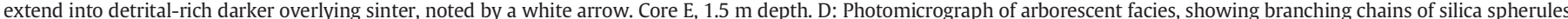

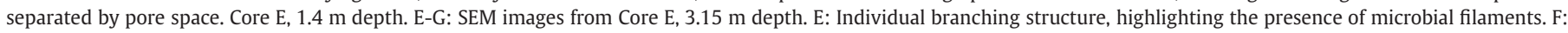
Magnified image of highlighted area in E, showing microbial filaments with associated angular detrital material. G: Microbial filaments without detrital material present.

filaments in porous laminae contort around curved fenestral margins in various orientations.

Palisades in Cores C, D, and E differ in fenestral size and morphology (Fig. 9A-C). Fenestrae in Cores $C$ and $E$ are sub-mm in scale, with subcircular margins in cross-section (Fig. 9A, C). By contrast, Core D fenestrae have elongated oval or lobate morphologies between 0.5 and $5 \mathrm{~mm}$ in diameter (Fig. 9B, D). Elongate fenestrae are especially prevalent in thicker porous layers of Core D. Long axes of such fenestrae are oriented normal to bedding planes, separated by thin vertical columns of silicified microbial filaments (Fig. 9D). Darker layers of Core D contain smaller, more circular fenestrae comparable to morphologies observed in Cores $\mathrm{C}$ and $\mathrm{E}$.

Filamentous microfossils are abundant in all fenestral palisades (Fig. 10A-C). In SEM images, Cores C and D exhibit round voids lined with $5-\mu \mathrm{m}$ wide filaments up to $100 \mu \mathrm{m}$ in length (Fig. 10A, B). Filaments retain equal diameter throughout their length, terminating with rounded, untapered ends. Individual microfossils frequently form bridges across fenestral pore spaces. While most sinters between fenestrae only preserve microfossils on exterior surfaces, exquisitely preserved regions reveal columnar bundles of filaments stretching across pore spaces (Fig. 10D, E). Secondary overprinting is especially prevalent in Core E, where microfossils are still abundant, but rounded fenestral textures are less distinct (Fig. 10C).

Palisades and similar microbial fabrics are globally present in hydrothermal sinter deposits of various ages (Walter, 1976a; Walter et al., 1996, 1998; Jones et al., 1997, 1998, 2005; Campbell et al., 2001, 2015; Konhauser et al., 2004; Fernandez-Turiel et al., 2005; Berelson et al., 

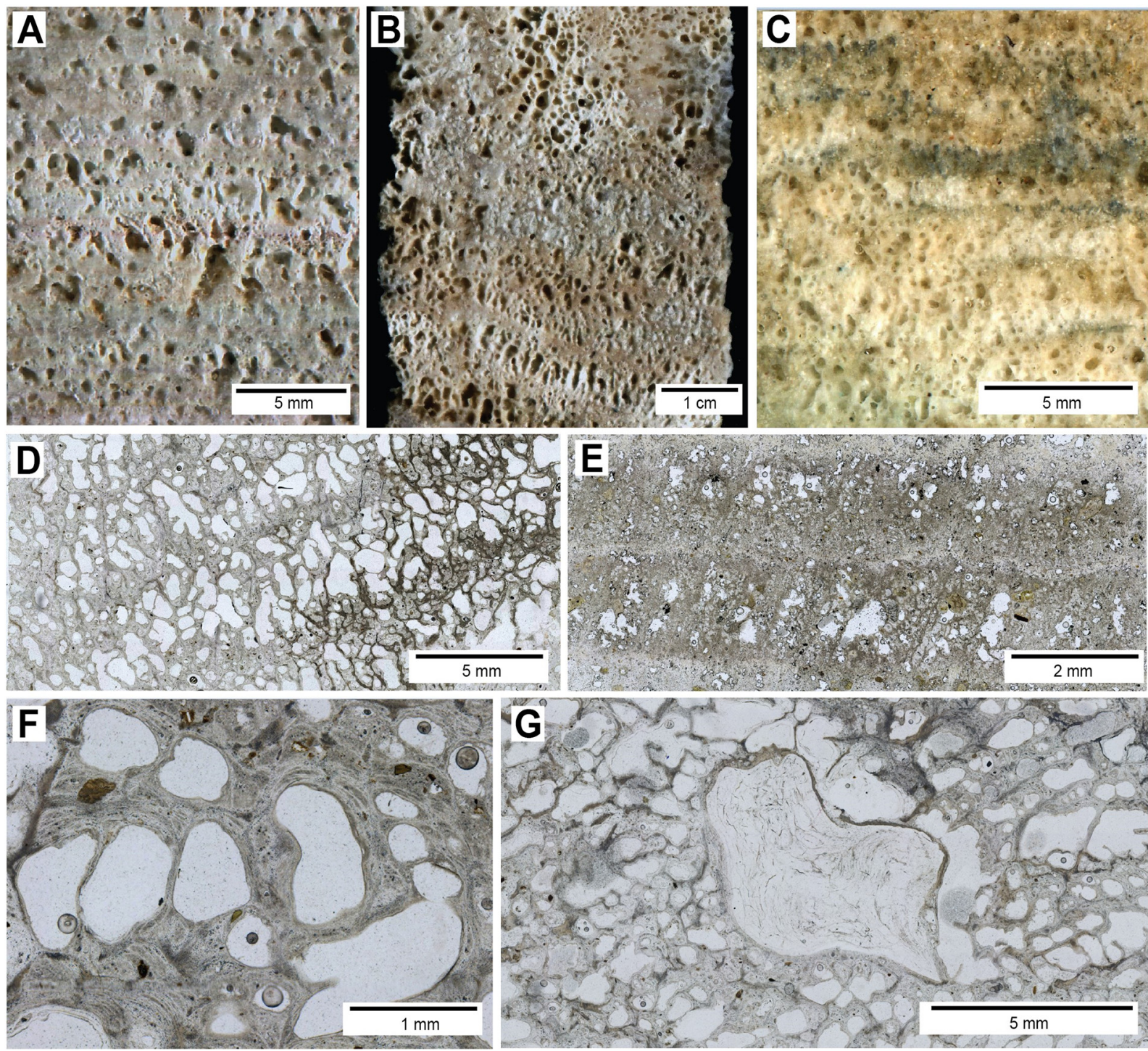

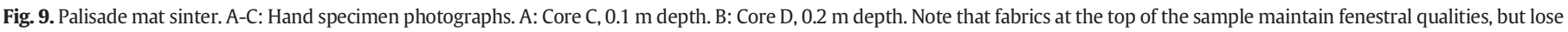

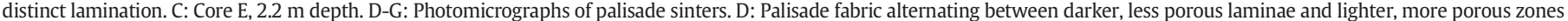

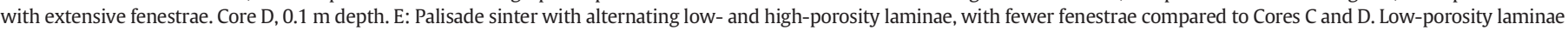

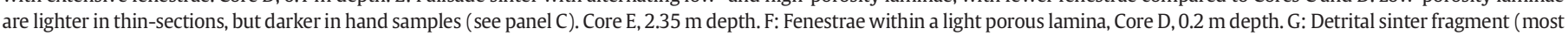
likely columnar or spicular) embedded in palisade fabric. Core D, $0.1 \mathrm{~m}$ depth.

2011; Gong et al., 2019). Variations in filament orientation are interpreted differently in various locations, including seasonal growth patterns (Walter, 1976a; Jones et al., 1998, 2005), pulses in hydrothermal sheetflow (Campbell et al., 2015), and quasi-daily shifts in water temperatures (Berelson et al., 2011). On steeper surfaces such as the edges of sinter mounds, palisade formation is driven by cycles of wetting and drying (Gong et al., 2019).

Palisade sinters closely resemble cyanobacterial communities living at or below $40-45^{\circ} \mathrm{C}$, typically interpreted as Calothrix (Walter, 1976a; Cady and Farmer, 1996; Campbell et al., 2001, 2015), though similar textures have been noted in communities of Fischerella, Phormidium, and Leptolyngbya (Jones et al., 2005; Pepe-Ranney et al., 2012; Gong et al., 2019). In active El Tatio geyser terraces, morphological and molecular evidence show a predominance of Leptolyngbya, and an absence of Calothrix or its more halotolerant sister genus, Rivularia (Gong et al., 2019). Due to the robust structures of Calothrix-type organisms, their absence is not likely due to a preservation bias, but rather interpreted as absence from the characterized terraces.
In many sinter localities, erect palisade filaments are often tightly packed together, leaving no space for mm-scale fenestrae. However, several locations contain more porous fenestral palisades in distal sinter aprons and terraces, including other zones in El Tatio (Jones et al., 1998; Munoz-Saez et al., 2016). One environmental exception occurs in Obsidian Pool Prime in Yellowstone National Park (Berelson et al., 2011; Mata et al., 2012), where fenestral textures occur in stromatolites around higher-temperature pool margins $\left(>45^{\circ} \mathrm{C}\right)$. However, Obsidian Pool Prime fenestrae have distinctly different morphologies from El Tatio cores, forming sub-spherical voids less than $1 \mathrm{~mm}$ in diameter. Instead, fenestrae in core samples more closely resemble elongate pores observed in cooler, distal settings elsewhere in El Tatio and New Zealand (Jones et al., 1998; Munoz-Saez et al., 2016).

\subsection{Tufted mat sinter}

Tufted mat sinters are defined as filamentous microbial mat textures with sharp peaks and cones irregularly separated by 1-2 mm concave 

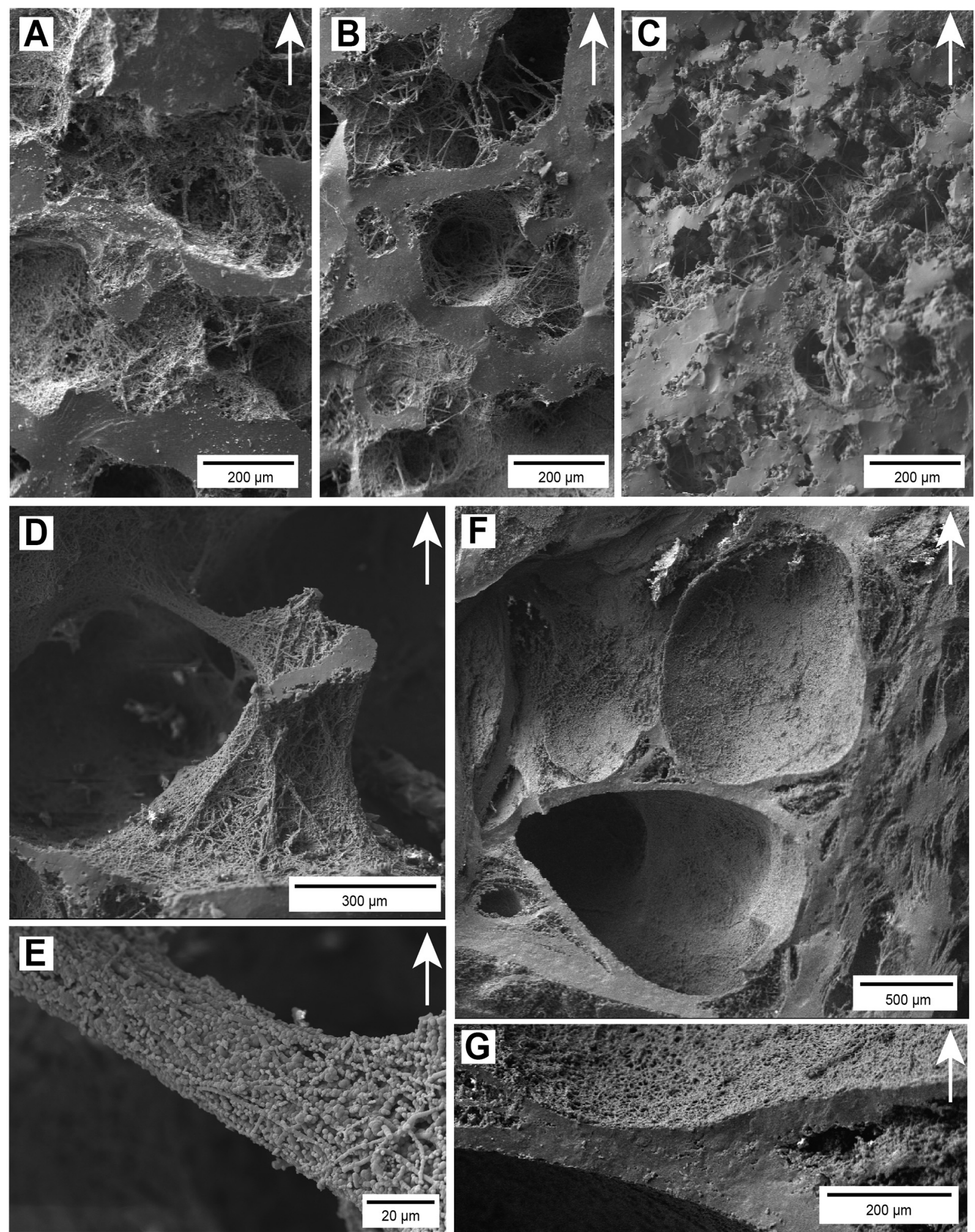

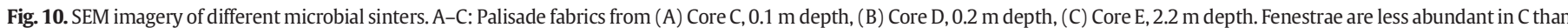

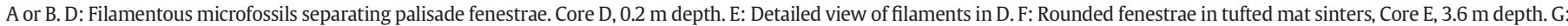
Detailed view of microbial sinter separating fenestrae in F, showing well-preserved microbial filaments on top of more silicified zones.

depressions (Cady and Farmer, 1996; Walter et al., 1996, 1998; Campbell et al., 2001; Jones et al., 2005), most notable in thin-section (Fig. 11A, B). Tufted facies occur within two zones of Core E (0-103 $\mathrm{cm}, 289-367 \mathrm{~cm}$ depth), interspersed as individual beds up to $15 \mathrm{~cm}$ thick. The top meter of Core E contains tufted beds interspersed between palisade fabrics, while lower units briefly occur between thicker units of arborescent sinters and laminated sandstone deposits. Individual tufted layers are $\sim 100 \mu \mathrm{m}$ thick, and are difficult to discern in hand samples. Laminae laterally increase in thickness to $200 \mu \mathrm{m}$ at tufted peaks, and diminish to $50 \mu \mathrm{m}$ in interstitial depressions. Textures 
immediately below tufts vary between layers. Most laminae do not preserve additional microbial textures below tufts (Fig. 11B), while some laminae contain relict microbial filaments (Fig. 11A). Occasionally, both highly circular and elongate fenestrae are preserved, bounded by thin pillars of filamentous sinter (Fig. 11C).
SEM imaging of tufted sinters shows exquisite preservation of microbial mat textures. Three-dimensional tufts are composed entirely of microbial filaments between 2 and $5 \mu \mathrm{m}$ in diameter (Fig. 11D-F). Filaments form diffuse meshwork textures at the base of tufts, while sharp peaks exhibit denser accumulations, reflecting differences in thickness
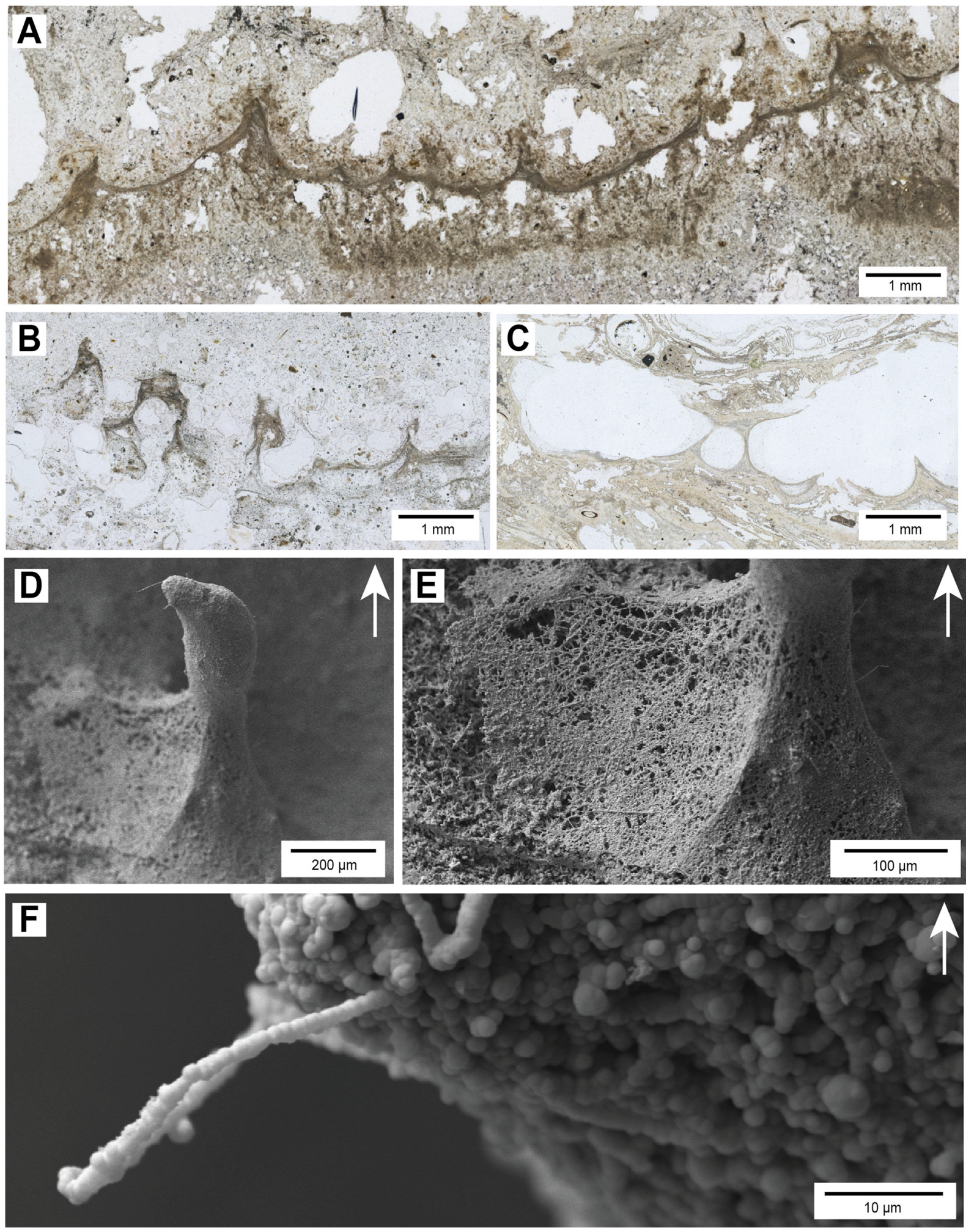

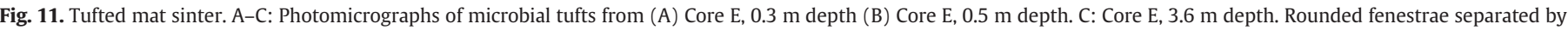

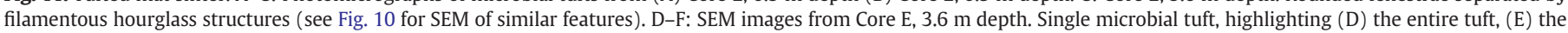
basal meshwork of filamentous microfossils, and (F) individual filaments near the tufted tip. 
and density observed in thin-sections (Fig. 11A, B). Large rounded fenestrae are also present, bounded and separated from each other by silicified filaments (Fig. 10F, G). Fenestrae are less frequent in tufted facies than palisades, but are larger and more spherical.

Tufted facies closely resemble modern mats dominated by the cyanobacterial taxa Phormidium and Leptolyngbya (Walter, 1976a; Campbell et al., 2001; Fernandez-Turiel et al., 2005; Lau et al., 2005; Bosak et al., 2012; Reyes et al., 2013; Bradley et al., 2017). Many tufted mats grow between 45 and $60{ }^{\circ} \mathrm{C}$ (Walter, 1976a; Campbell et al., 2001; Lau et al., 2005; Bradley et al., 2017), though tufted Leptolyngbya mats are also reported between 17 and $45^{\circ} \mathrm{C}$ (Bosak et al., 2012; Reyes et al., 2013). Large rounded fenestrae below tufts are also distinct from fenestral palisade textures, more closely resembling spherical gas bubbles preserved within tufted hydrothermal mats (Lynne and Campbell, 2003; Bosak et al., 2009, 2010; Mata et al., 2012). Tufted facies are interspersed with palisade fabrics in the top meter of Core $\mathrm{E}$, with changes in mat morphology potentially facilitated by changes in water temperatures or hydrochemistry.

\subsection{Massive sinter}

Massive sinters exhibit either obscured or no primary features such as laminae, bedding, detrital grains, or microfossils (Fernandez-Turiel et al., 2005; Walter et al., 1996). Massive sinter facies occur at various depths in Cores A, D, and E. The lowest meter of Core A consists of green and gray low-porosity sinter with pale yellow and orange minerals along secondary fissures (Fig. 12A). While massive Core A sinter contains vertically oriented lineations in hand sample similar to inclined sinter crusts, all traces of vertical fabric are obscured in thin section (Fig. 12B). Sinters at the base of Core D $(72-97 \mathrm{~cm})$ have similarly low porosity, and lack bedding, vertical lineation, or clear laminae in hand sample or thin section (Fig. 12C). Massive sinters occur in 5-cm thick beds at various depths in Core E (130-135 cm, 320-325 cm, 330-335 $\mathrm{cm})$. Core $\mathrm{E}$ facies are lighter in colour than in Cores A and D, and have gradational contacts with particulate and arborescent sinters. Microscopy of massive sinters and adjacent facies also shows extensive growth of secondary silica phases within pore spaces (Fig. 12D, E).

Massive sinter fabrics are present in modern and ancient sinter deposits (Walter, 1976a; Walter et al., 1996; Guidry and Chafetz, 2003a). The lack of primary fabrics in hand samples and thin-sections implies secondary alteration, such as recrystallization and overgrowth of original sinter deposits, most likely by high temperature silica-rich subsurface fluids. Adjacent primary facies in Cores A and E support a high-temperature alteration hypothesis. Massive sinter in Core A is overlain by more than 2 $\mathrm{m}$ of inclined and planar sinter crusts, representing the sides and floors of vent-proximal pools respectively. In Core E, massive sinters are associated with particulate sinters, also interpreted as subaqueous deposits near secondary hydrothermal vents distal to Mound 502. In contrast, facies at the base of Core D are not associated with high-temperature pool or vent facies. Based on high-temperature associations elsewhere, massive sinters in Core D are interpreted as former microbial mat sinters which were secondarily altered by subsurface fluid flow and recrystallization.

\subsection{Laminated sandstone and sinter}

Laminated sandstone and sinter (LSS) deposits are defined as interbedded siliciclastic and sinter layers between 0.1 and $5 \mathrm{~cm}$ thick. The LSS facies is only observed in the lower $2.5 \mathrm{~m}$ of Core E. Sandstones are medium- to coarse-grained, and are composed of sub-rounded to sub-angular volcaniclastic grains and occasionally detrital sinter pieces (Fig. 13A, C, E). No evidence of cross-bedding is observed in sandstone beds, while sinters contain millimeter- scale planar laminae lacking fenestrae or filaments. Laminated sinters often have irregular, unconformable contacts with overlying sandstones.

The ratio of sinter to sandstone in LSS facies varies in different areas of Core E. Below $4 \mathrm{~m}$ depth, sandstone layers are thicker, containing isolated, centimeter-scale sinter deposits. Unconformities separate lower LSS facies from intervening massive sandstones lacking sinter in Core E (described below). LSS facies above $4 \mathrm{~m}$ in Core $\mathrm{E}$ are dominated by planar sinter, punctuated with sub-centimeter sandy layers. Upper LSS facies in Core E are typically less than $5 \mathrm{~cm}$ thick and are often under- or overlain by tufted microbial textures, distinguished by filamentous fabrics.

LSS facies in Core E are interpreted as distal sheet-flow deposits, with sinter layers representing relative lulls in siliciclastic input. Beds below 4 $m$ depth indicate higher-energy environments where clastic sedimentation prevented persistent sinter deposition. In contrast, LSS facies above $4 \mathrm{~m}$ depth exhibit minor pulses of siliciclastic deposition in a calmer, sinter-dominated regime. In both zones, sinter deposits were consistently eroded by subsequent sandstone deposition, forming irregular upper contacts.

\subsection{Massive sandstone}

Massive sandstones contain no bedding textures or interstitial sinter deposits, and are only found in the lowest meter of Core E. Similar to LSS facies, sands are medium to coarse-grained, and are composed of subrounded and sub-angular volcaniclastic grains (Fig. 13B, D, F). The majority of siliciclastic material is composed of volcanic lithic fragments, feldspar, mica and minor portions of redeposited sinter material. The sandstone is notably free of detrital quartz, but largely cemented by siliceous material such as opal and chalcedony (Fig. 13F).

Massive sandstone units have unconformable boundaries with adjacent sinter and sandstone beds, and occasionally contain unconformities within otherwise homogenous units. One notable unconformity occurs at $538 \mathrm{~cm}$ depth in Core E. Sandstones containing 1-2 cm wide matrix-supported rounded green clasts are conformably overlain by planar beds of sands fining upward from coarse to medium-grained. Both units are eroded by an unconformably overlying homogenous, coarse-grained sandstone. Vitreous brown cements follow the unconformity, cross-cutting into over- and underlying sediments (Fig. 13B). No other sedimentary structures are apparent in massive sandstones.

Massive sandstones are interpreted as debris flows with little to no hydrothermal influence. The only hydrothermal silica precipitation present $(538 \mathrm{~cm}$ ) occurs as secondary precipitation following unconformities and cross-cutting primary lithologies in a narrow zone.

\section{Core geochemistry}

Sinters in Cores A, C, D, and the upper $4 \mathrm{~m}$ of Core E are largely composed of siliceous material with more than $94 \mathrm{wt} \%$ of $\mathrm{SiO}_{2}$ (Fig. 14). Cores closer to the vent source (A, C, D) are especially enriched in $\mathrm{SiO}_{2}$, with all measured values above $98.5 \mathrm{wt} \% . \mathrm{SiO}_{2}$ concentrations in Cores $\mathrm{A}$ and $\mathrm{C}$ decrease towards surface deposits, with higher values in sinter crusts and columnar sinters, and lower values in mat and particulate sinter facies. Core D shows little variability between massive sinters and palisade mat facies, while sandstones at the base of Core $\mathrm{E}$ are relatively $\mathrm{SiO}_{2}$-depleted (70-85 wt\%), with a sharp increase to $>90$ wt\% at $361 \mathrm{~cm}$ depth. $\mathrm{SiO}_{2}$ concentrations in Core E increase to $99 \mathrm{wt}$ $\%$ in arborescent, particulate and massive sinters between 1 and $2 \mathrm{~m}$ depth before slightly decreasing within the uppermost meter of mat facies, in a similar fashion to Cores A and C (Fig. 14).

Other major elements are anti-correlated to $\mathrm{SiO}_{2}$ concentrations in all cores (Fig. 14, Supplementary Information). For example, $\mathrm{Al}_{2} \mathrm{O}_{3}$, $\mathrm{Fe}_{2} \mathrm{O}_{3}, \mathrm{TiO}_{2}$, etc. increase upwards in Cores $\mathrm{A}$ and $\mathrm{C}$ as $\mathrm{SiO}_{2}$ decreases. In Core $\mathrm{E}$, sandstones below $4 \mathrm{~m}$ depth have different geochemical signatures than overlying sinters. Many elements are several orders of magnitude more abundant in Core E sandstone deposits (Fig. 14), including $\mathrm{Al}_{2} \mathrm{O}_{3}$ concentrations above $10 \mathrm{wt} \%$. In Core $\mathrm{E}$ sinter facies above $4 \mathrm{~m}$ depth, elemental abundances reach minimum values at $\sim 2$ $\mathrm{m}$ (e.g., $\mathrm{Al}_{2} \mathrm{O}_{3}$ concentrations at $0.1 \mathrm{wt} \%$ ) before slowly increasing within the top meter of mat sinter facies. While certain elements are 

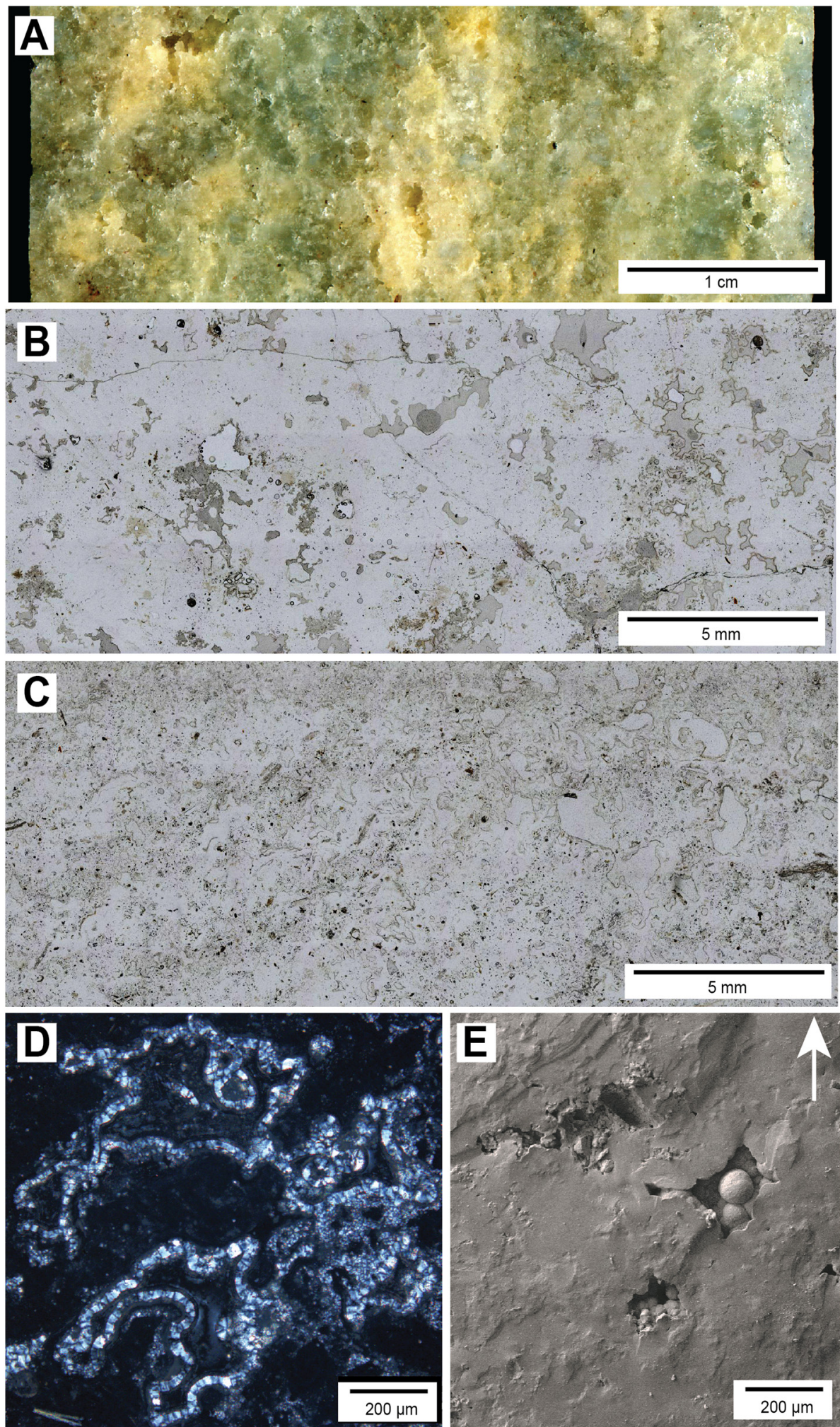

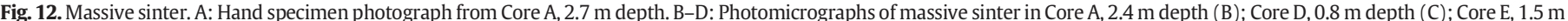

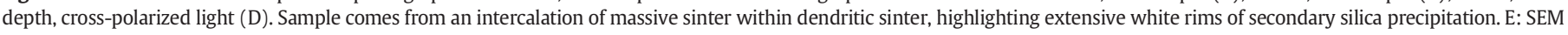
image from Core E, $1.9 \mathrm{~m}$ depth.

elevated in individual layers (e.g., $\mathrm{P}_{2} \mathrm{O}_{5}$ in Core E, $103 \mathrm{~cm}$ ), larger shifts are consistent between elements in all cores.

Most trace elements exhibit similar stratigraphic trends to major elements in all four cores. For example $\mathrm{Li}, \mathrm{Cs}, \mathrm{Rb}, \mathrm{Se}, \mathrm{U}, \mathrm{Cr}$, and many other elements are enriched in Core $\mathrm{E}$ sandstones below $4 \mathrm{~m}$ depth, and depleted in overlying sinters, with slightly higher concentrations of $\mathrm{Li}$ and Cs (Supplementary Information). In rare cases, certain elements are enriched in sinters compared with clastic deposits. For example, Sb concentrations increase in Core E sinters above $4 \mathrm{~m}$, and represent the most abundant trace element in all sinter samples (Supplementary 

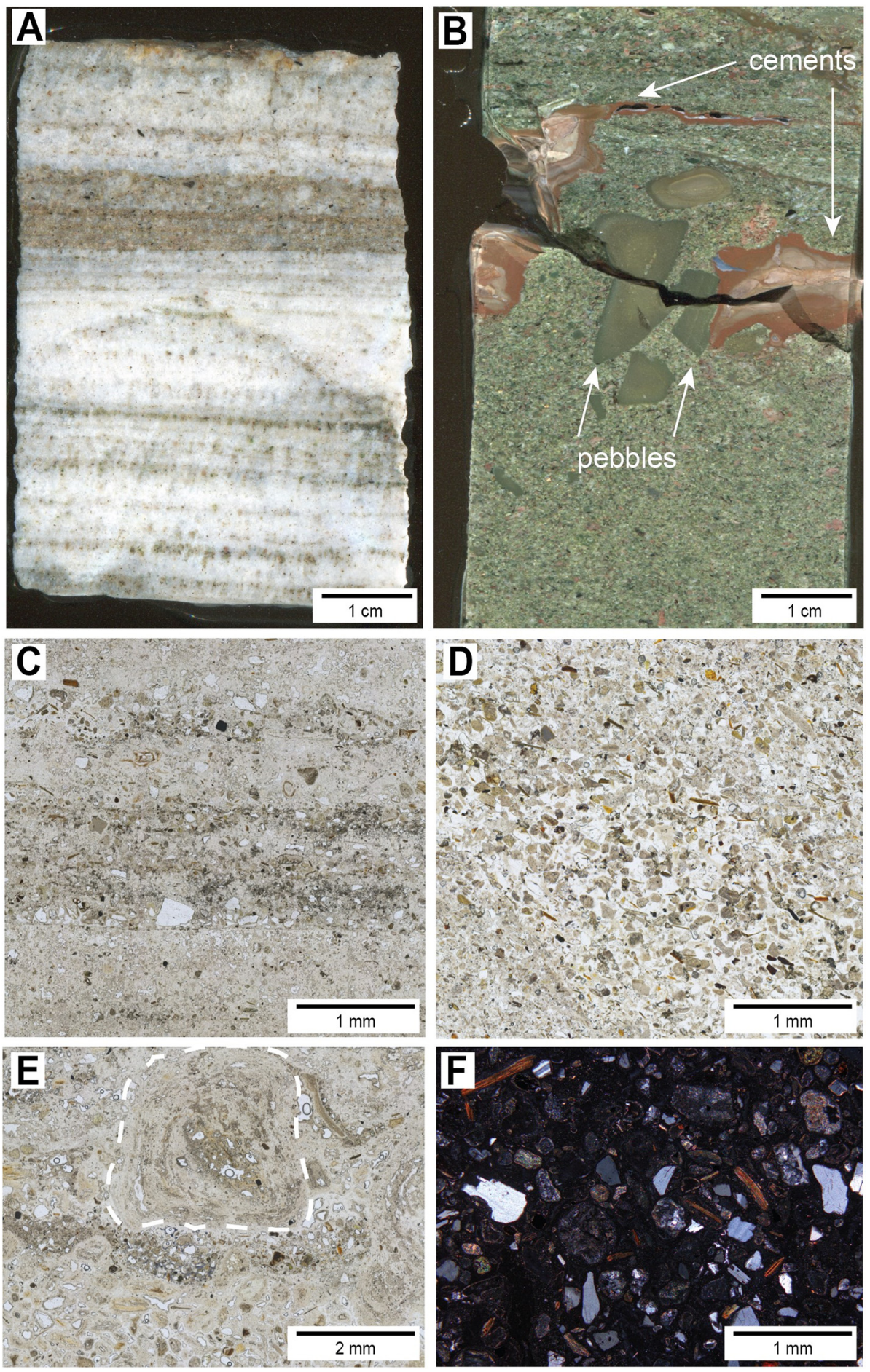

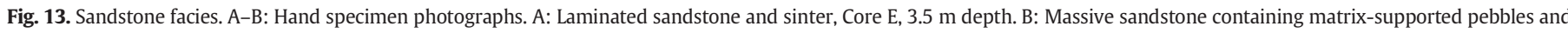

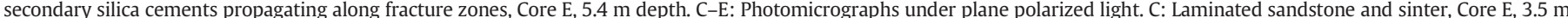

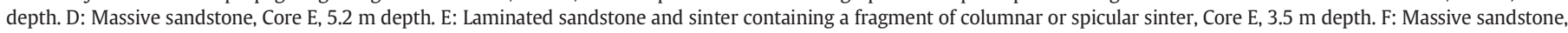
photomicrograph in cross-polarized light, Core E, $5.2 \mathrm{~m}$ depth.

Information). As is slightly more abundant in sinter than sandstone facies, with elevated concentrations in the top $0.5 \mathrm{~m}$ of all cores (Supplementary Information).

Rare earth element (REE) core profiles are nearly identical to most major and trace elements, with strong anti-correlation to $\mathrm{SiO}_{2}$ concentration (Figs. 14, 15). When REE concentrations of individual samples are normalized to clastic deposits of Mound 502, neither light nor heavy rare earth elements (LREE and HREE) are enriched (Fig. 15, Supplementary
Information). Slight HREE enrichment occurs when core samples are normalized to chondritic meteorites and post-Archean Australian shale (PAAS) (Supplementary Information).

Total REE abundance increases towards the tops of Cores A and C, with a slight decrease around $1.2 \mathrm{~m}$ depth in Core A (Fig. 15). Core D has consistent REE concentrations over a limited sampling distribution. As with major elements, REE concentration in Core E varies greatly based on depth and facies. Sandstones below $4 \mathrm{~m}$ depth have concentrations one 


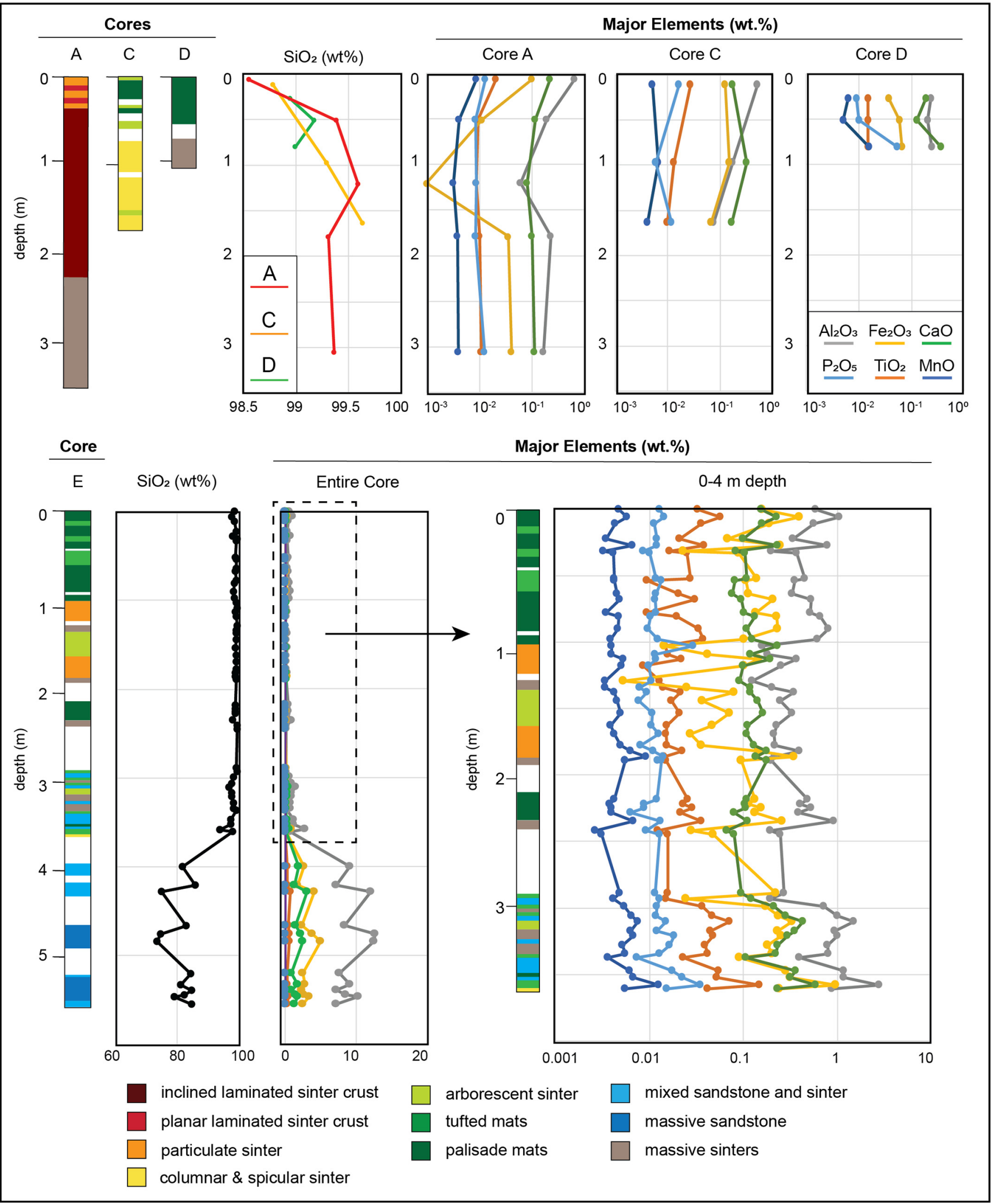

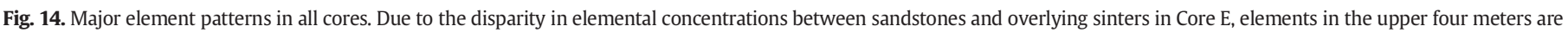
shown separately on different axes. Detailed concentration and depth measurements for all major and trace elements are in the Supplementary Information. 
to two orders of magnitude higher than overlying sinters, forming a sample population distinct from facies in any other core (Fig. 15). REE abundance drops drastically by approximately one order of magnitude at 4 $m$ depth, when sinter becomes more abundant relative to sandstone. Between ca. 3.6 and $3.0 \mathrm{~m}$ depth, REE abundance decreases steadily by one order of magnitude where sandstone bearing beds become less abundant (Fig. 15). Arborescent and particulate sinters between 1 and $2 \mathrm{~m}$ contain the lowest REE concentrations in Core E, with values gradually increasing in overlying mat facies.

Different core facies also vary in REE patterns between individual samples (Fig. 15). When normalized to values of clastic deposits within Mound 502, REE patterns are essentially flat in facies with elevated concentrations, such as LSS and various microbial mat facies. In samples with depleted REE, certain elements are relatively enriched, including La, Eu, Y, and Lu (Fig. 15). Enrichment of such elements typically increases as total REE concentration decreases, and is most prevalent in sinter crust, particulate, and columnar sinter facies. For example, positive Eu anomalies (enrichments in Eu relative to clastic material, see Methods) are highest in sinter crust and columnar facies in Cores A and $C$, respectively (Figs. 15, 16). The highest positive Eu anomalies in Core E occur in particulate sinters between 1.5 and $2.0 \mathrm{~m}$ depth, with all other facies exhibiting slightly negative or no Eu anomalies (Fig. 16).

\section{Discussion: core depositional histories}

Depositional interpretations based on core sedimentology are wellsupported by geochemical data, especially regarding proxies for siliciclastic material relative to mineral precipitation in hydrothermal fluids. For example, Al-concentration in chemical sediments is frequently used as a proxy for siliciclastic components, such as clay minerals and feldspar (Calvert, 1976; Tribovillard et al., 2006). The high concentration of $\mathrm{Al}_{2} \mathrm{O}_{3}$ and other elements in sandstone beds compared with sinters confirms such interpretations for El Tatio systems (Fig. 14). Therefore, subtle differences in $\mathrm{Al}_{2} \mathrm{O}_{3}$ and associated elements within sinters can determine relative siliciclastic input and corroborate environmental interpretations based on sedimentary structures. Similarly, positive Eu anomalies are often applied as a proxy to estimate the relative influence of hydrothermal fluids on lithologies (Michard, 1989; Lewis et al., 1997; Feng et al., 2014). On broad lateral scales, positive Eu anomalies in El Tatio cores are larger with proximity to the vent source (Fig. 16). Such trends confirm the utility of Eu anomalies within cores to determine relative fluctuations in hydrothermal activity.

$\mathrm{Al}$ and Eu proxies appear to be broadly connected in El Tatio cores, with samples forming a spectrum between two geochemical endmember proxies. Facies with higher $\mathrm{Al}_{2} \mathrm{O}_{3}$ concentrations such as sandstones and microbial mat sinters have little to no Eu anomaly, while samples with high positive Eu anomalies (sinter crust, particulate, columnar sinters) have relatively low $\mathrm{Al}_{2} \mathrm{O}_{3}$ abundance (Figs. 14-16). This dichotomy is most likely due to differences in REE abundance between hydrothermal sinters and detrital sandstones. Sandstones have the highest $\sum$ REE in any core facies, with values orders of magnitude above associated sinters (Fig. 15). The abundance of REE in sandstone implies that even a relatively minor siliciclastic component in sinter can overpower the REE signature of depleted sinters. Separating $\sum$ REE into LREE or HREE reveals no enrichment of either group in clastic-normalized samples (Fig. 15), while normalizations to other standards reveal only minor enrichments in HREE (Supplementary Information).

Therefore, in El Tatio cores, positive Eu anomalies are conservatively interpreted as the relative influence of hydrothermal precipitation compared to siliciclastic influx. The dichotomy between $\mathrm{Al}_{2} \mathrm{O}_{3}$ concentrations and Eu anomalies persists across all four cores, and matches interpretations based on sedimentary and geochemical evidence. Distal environments have higher abundances of siliciclastic material relative to hydrothermal silica precipitation than vent-proximal zones. Microbial mats in particular are noted for trapping detrital material with filamentous textures and adhesive extracellular polymers (Gebelein, 1969; Riding, 2000; Frantz et al., 2015).

Trace element proxies support previous observations of El Tatio water and sinter chemistry. Two primary types of hydrothermal fluids exist in the El Tatio geyser field: alkali-chloride and acid-sulfate (Giggenbach, 1978; Cortecci et al., 2005). Alkali-chloride waters in El Tatio are enriched in As, Cs, and Li, while acid-sulfate waters are only enriched in B compared to meteoric sources (Cortecci et al., 2005). While B was not examined in this study, cored sinters are slightly enriched in Li, Cs, and As compared with most other trace elements (Supplementary Information), indicating the presence of alkalichloride waters similar to modern Upper Basin environments (Giggenbach, 1978; Cortecci et al., 2005). In addition, elevated concentrations of Sb in Mound 502 sinters are consistent with previous sinter studies at El Tatio and other Chilean hydrothermal zones (Landrum et al., 2009; Sanchez-Yanez et al., 2017). Combined sedimentary and geochemical data therefore provide depositional histories for each core and form a local model for sinter mound growth (Fig. 17).

\subsection{Core A}

Core A was drilled on top of Mound 502, along the inner rim of the steep-walled inner pit. Core A is the first sedimentary core described from vent-proximal sinter deposits, and it provides several insights into high-temperature facies which corroborate observations of active modern hydrothermal systems.

The lowermost meter of Core A is massive sinter, showing no primary texture in hand sample or thin section (Fig. 12A, B). Massive facies contain low $\mathrm{Al}_{2} \mathrm{O}_{3}$ concentrations and a significant positive Eu anomaly (Figs. 14-16), indicating extensive silica precipitation in hydrothermal waters with low siliciclastic input. Such precipitation can occur during primary vent-proximal deposition or secondary subsurface alteration. While specific depositional features are absent, $\mathrm{Al}_{2} \mathrm{O}_{3}$ concentrations in massive sinters as low as $0.16 \mathrm{wt} \%$ indicating very little to no siliciclastic input. Therefore, we interpret massive Core A sinters as vent-proximal hydrothermal deposits secondarily altered by subsurface flow, consistent with previous studies of massive sinter (Walter, 1976b; Walter et al., 1996; Guidry and Chafetz, 2003a).

Inclined sinter crust is only observed in Core A, forming a nearly continuous unit $2 \mathrm{~m}$ thick. Depositional angles and bed thicknesses correspond to the surficial topography of Mound 502's inner pit, which descends $\sim 1.5 \mathrm{~m}$ below rim margins (Fig. 1D). Sinters from $121 \mathrm{~cm}$ depth contain the lowest measured concentrations of $\mathrm{Al}_{2} \mathrm{O}_{3}$ and $\sum$ REE in all core samples, as well as the highest percentages of $\mathrm{SiO}_{2}$ and a strongly pronounced positive Eu anomaly (Figs. 14-16). Geochemistry and sinter topography support the presence of a hightemperature pool sourced by subsurface hydrothermal fluids (Fig. 17), currently represented by the inner pit of the extinct mound. Microscopic surface-normal silica fabrics support a hydrothermal pool interpretation for sinter crusts (Figs. 3, 4), closely resembling fabrics observed in subaqueous conditions over $73{ }^{\circ} \mathrm{C}$ in Yellowstone pools (Lowe and Braunstein, 2003). While microbial textures are occasionally observed in SEM, the prevailing surface-normal fabrics more closely resemble ambiguously biogenic "shrub columns" (Jones and Renaut, 2003) or abiogenic "dendritic sinter fabrics" (Lowe and Braunstein, 2003), forming when silica precipitation outpaces microbial growth.

Positive Eu anomalies and $\mathrm{SiO}_{2}$ percentages decrease further up section while $\mathrm{Al}_{2} \mathrm{O}_{3}$ concentrations increase, indicating an increase in siliciclastic input relative to sinter precipitation. An angular unconformity separates inclined sinter crusts from overlying planar facies. Planar sinter crusts match the flat-topped topography of Mound 502's inner rims, potentially signifying a shift from silica accretion within steepsided pools to vertical build-up of pool-side margins (Fig. 17). No textural features in planar crusts indicate the presence of microbial mats or indicate biological mediation of silica precipitation. The top ten centimeters of Core A are particulate sinter with abundant siliciclastic 


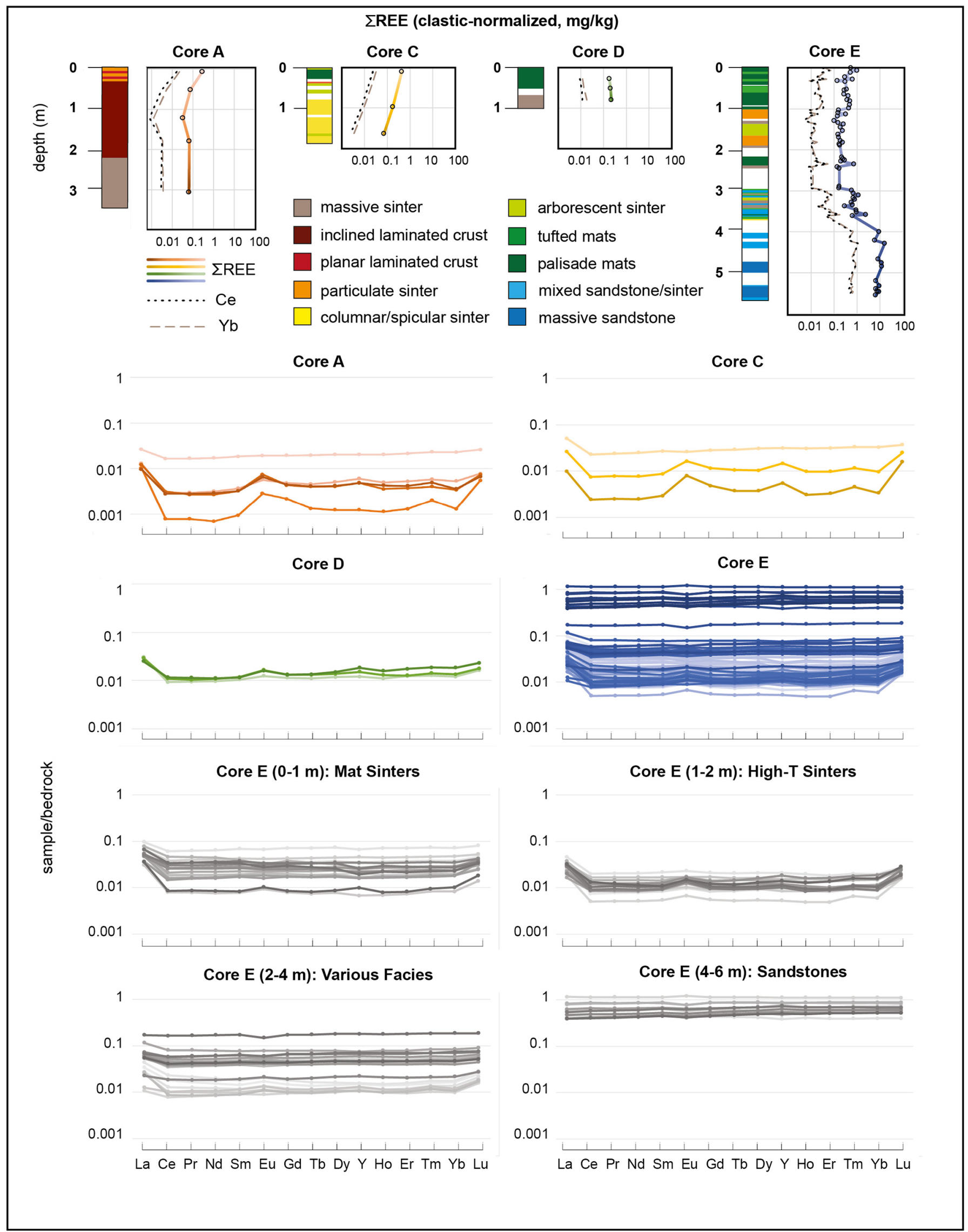

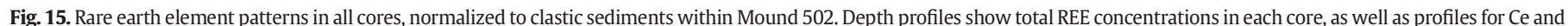

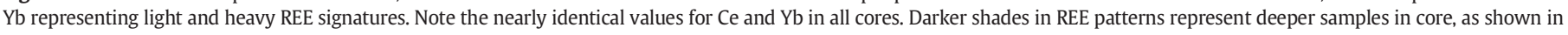
profiles. Core E is further split into four sub-sections dominated by different facies. Specific values are in the Supplementary Information. 


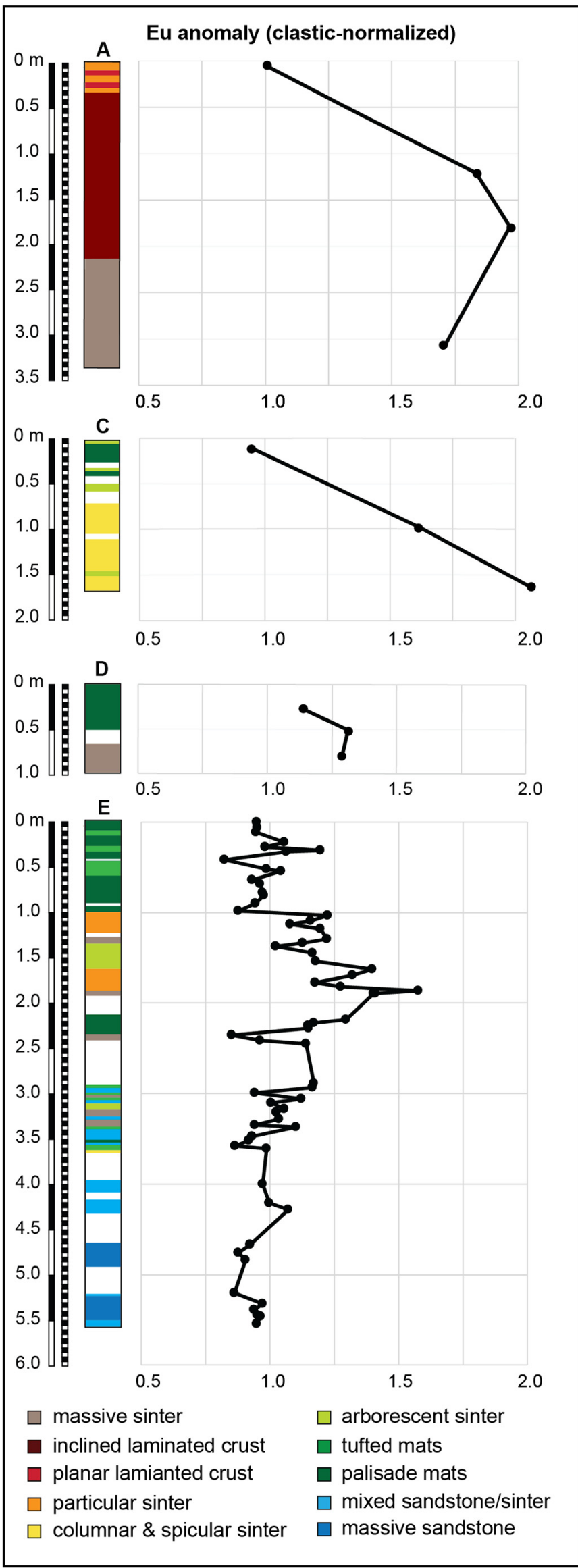

grains visible in hand sample, signifying a decrease in relative hydrothermal activity compared to clastic sedimentation (Fig. 17).

Vent-proximal sinter facies are frequently studied in active hydrothermal systems, exhibiting a diverse range of environments including geysers and pools with varying degrees of boiling, surging, and overflow (Braunstein and Lowe, 2001; Guidry and Chafetz, 2003a, 2003b, 2003c; Lowe and Braunstein, 2003; Hinman and Walter, 2005). However, the stratigraphy of high-temperature vents is less well-understood. The most detailed vent-proximal stratigraphy comes from Devonian sinters in the Drummond Basin of Australia (Walter et al., 1996, 1998). Extensive stratigraphic columns of Drummond exposures revealed several hightemperature facies: massive and brecciated sinters interpreted as subsurface or altered vent zones, as well as thin flat-bedded and "diffusely layered" sinters interpreted as pool-bottom facies (Walter et al., 1996). No particulate facies or inclined sinter crusts with surface-normal fabrics are described in Drummond sinters. Vent-proximal sinters are spread out in areas over $>100 \mathrm{~m}^{2}$ in the Drummond Basin, and are frequently intercalated with lower-temperature mat facies, reaching no more than $50 \mathrm{~cm}$ thickness. In contrast, inclined sinter crusts and massive facies in Core A are over one meter thick, and do not contain the extensive microbial mat textures observed in Cores C, D, and E. The differences between Core $\mathrm{A}$ and Drummond strata highlight the diversity in vent-proximal facies, and the need for further stratigraphic investigation.

\subsection{Core C}

Core $C$ was drilled five meters to the east and $1.5 \mathrm{~m}$ below the top of Core A, on the outer margin of Mound 502. The lower meter of Core $\mathrm{C}$ is a nearly continuous unit of distinctive columnar sinter (Figs. 6, 7). Despite the major morphological differences between columnar sinters in Core $\mathrm{C}$ and sinter crusts in Core $\mathrm{A}$, both have similar chemical signatures. $\mathrm{Al}_{2} \mathrm{O}_{3}, \sum \mathrm{REE}$, and many other elements increase in roughly equivalent concentrations up-section, while $\mathrm{SiO}_{2}$ shows a steady decrease by $\sim 1 \mathrm{wt} \%$ (Figs. 14, 15). Positive Eu anomalies near the base of Core $\mathrm{C}$ are the highest in any core, including sinter crust facies in Core A (Fig. 16). The geochemical signatures indicate a high-temperature depositional environment with little to no siliciclastic input (Fig. 17). Such interpretations are strongly supported by current observations of columnar and spicular sinter formation in splash and spray zones close to hydrothermal vents and pools (Walter, 1976b; Jones et al., 1997, 1998; Braunstein and Lowe, 2001; Lowe and Braunstein, 2003; Jones and Renaut, 2003; Guidry and Chafetz, 2003a).

Despite the general consistency of columnar morphologies in Core C, several hiatuses and depositional changes are present. The transition from mm-scale spicules to $\mathrm{cm}$-scale columns at the base of Core $\mathrm{C}$ is separated by a brief section of missing core. The sequence most likely represents a depositional hiatus between splash zones immediately adjacent to a hydrothermal vent, and surge-flow zones forming larger columns further away from hydrothermal activity. At $1.5 \mathrm{~m}$ depth, laminated arborescent sinter immediately overlies horizontal columns, with no evidence of intervening erosional activity (Fig. 6E). Overlying columnar sinters maintain similar widths and branching morphologies, but form at increasing depositional angles over the next $70 \mathrm{~cm}$ (Fig. 6C, D). The brief interval of arborescent sinter formation indicates an outflow-dominated period with active microbial communities colonizing the sinter (Fig. 6E).

Microbial cells and their growth textures are either extremely altered or absent in columnar sinter facies (Fig. 7F, G), as opposed to abundant and well-preserved textures in palisade mat fabrics overlying

Fig. 16. Europium anomalies in all cores. Values are unit-less, and represent the relative enrichment or depletion of Eu compared to Sm and Gd in relation to Eu concentrations of clastic material (See Section 3.4 for calculations). Specific anomaly values are presented in the Supplementary Information. Values above 1 are enriched in Eu, and are interpreted here as a proxy for the relative influence of high-temperature hydrothermal fluid compared to clastic sedimentation. 

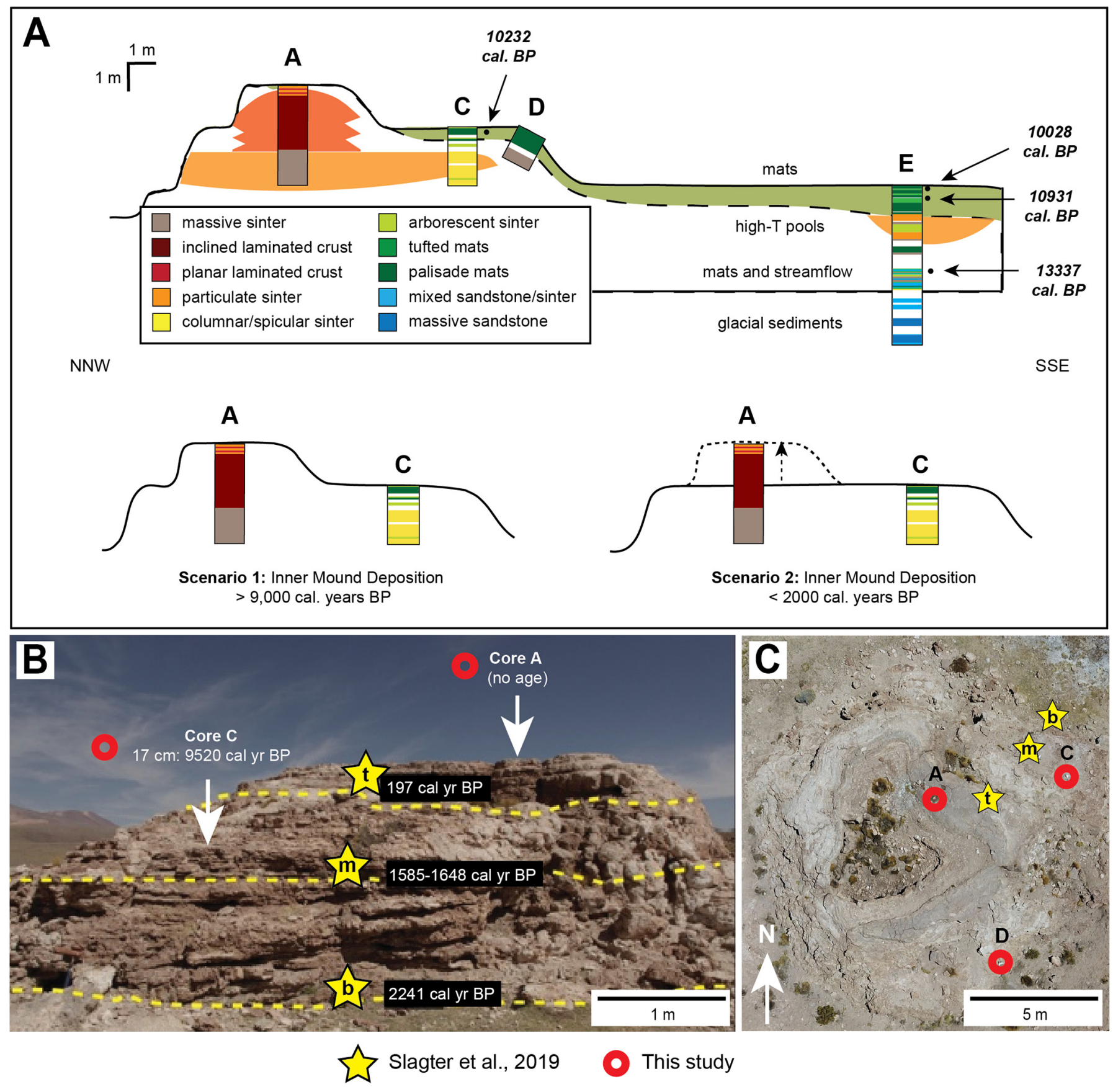

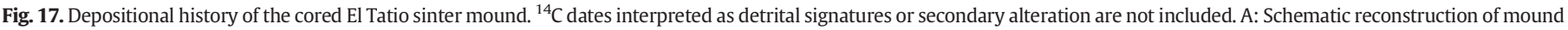

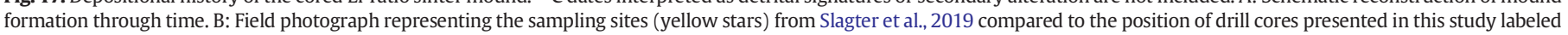
with white arrows, modified from Slagter et al., 2019. C: Drone image showing the mound from above, representing the position of the features described in B.

columnar sinters (Figs. 9, 10). Columnar facies in various locations appear to form with or without the presence of microbial communities (Walter, 1976b; Jones et al., 1997, 1998; Braunstein and Lowe, 2001; Jones and Renaut, 2003; Lowe and Braunstein, 2003). As with sinter crusts, the paucity of microbial textures in well-preserved columns does not preclude the earlier presence of microbes, but supports the dominance of abiogenic processes of sinter growth.

Palisade mats in the top meter of Core $C$ contain chemical signatures with no Eu anomalies and elevated siliciclastic signatures (Figs. 14-16). Palisade mats are typically interpreted as forming at water temperatures at or below $40-45^{\circ} \mathrm{C}$ (Walter, 1976a; Campbell et al., 2015; Gong et al.,
2019), though the lack of an Eu-anomaly combined with higher concentrations of $\mathrm{Al}_{2} \mathrm{O}_{3}$ in Core $\mathrm{C}$ palisades is more indicative of increased detritus than relative temperature. Arborescent sinter appears as thin interstitial layers between palisade-mat sinters, and separate palisade mat facies from underlying columnar facies at $0.5 \mathrm{~m}$ depth. No chemical data was collected from arborescent sinters, but visual observations of detrital grains, and comparisons with "siliceous shrubs" from Yellowstone imply outflow channels with potentially higher discharge than palisade mat facies. The top half meter of Core $C$ is interpreted as a shift from a hot splashing zone to more clastic-dominated outflow environments with occasional pulses of hydrothermal activity (Fig. 17). 
While columnar and spicular sinters of Core $C$ are well-described from surface deposits in active and recently inactive hydrothermal settings (Walter, 1976b; Jones et al., 1997, 1998; Braunstein and Lowe, 2001; Lowe and Braunstein, 2003; Jones and Renaut, 2003; Guidry and Chafetz, 2003a), this study is the first to observe columnar sinters in drill core. Similar laminated columns ( $\leq 20 \mathrm{~cm}$ long) were observed in stratigraphic studies of Devonian sinters from the Drummond Basin in Australia (Walter et al., 1996, 1998), but poor exposure prevented correlation to adjacent facies. In contrast, the transition from columnar to palisade facies in Core $\mathrm{C}$ records a depositional shift from splash and surge-dominated forces to extensive microbial preservation.

\subsection{Core $D$}

Core D was drilled $6 \mathrm{~m}$ southeast of Core A, starting at a roughly equivalent elevation to Core C (Fig. 1E). Unlike the vertical cores of A, $\mathrm{C}$, and $\mathrm{E}, \mathrm{D}$ was drilled at a $27^{\circ}$ angle from vertical alignment along the outer edge of Mound 502, with the drilling axis pointed towards the NW. Core D is the shortest core, and contains the lowest diversity in sedimentary facies and geochemical signatures.

Massive sinters at the base of Core D are not visibly associated with high-temperature facies, such as sinter crusts, particulate, or columnar sinters, although such deposits could underlie the core base (Fig. 2). However, the single chemistry data point within massive sinters is nearly identical to overlying palisade mat facies, with a minor positive Eu anomaly and a moderate siliciclastic signature (Figs. 14-16). Massive facies in Core D are therefore interpreted as relatively distal sinters secondarily altered by subsurface fluid flow (Fig. 17).

Fenestral palisade fabrics at the top of Core $\mathrm{D}$ are nearly identical to facies observed in Cores C and E (Fig. 9B), preserving microbial communities visible in thin-section and SEM imaging. Chemical analyses reveal slight differences between palisade sinters of different cores, with Core $\mathrm{D}$ palisades bearing slightly higher positive Eu anomalies and lower siliciclastic signatures such as $\mathrm{Al}_{2} \mathrm{O}_{3}$ than Cores $\mathrm{C}$ and $\mathrm{E}$ (Figs. 14-16). While it is possible that Core $\mathrm{D}$ mats were deposited under warmer conditions than other palisade textures, the relative lack of data keeps temperature estimates conservatively around $40-45{ }^{\circ} \mathrm{C}$ as described in previous surficial and stratigraphic studies (Walter, 1976a, Walter et al., 1996, 1998; Jones et al., 1998; Lynne et al., 2008; Campbell et al., 2001, 2015, 2020; Gong et al., 2019). In either case, the top of Core D matches broad trends observed in surficial facies of all cores, featuring strata deposited in cooler water temperatures with higher amounts of siliciclastic material before termination of hydrothermal activity (Fig. 17).

\subsection{Core E}

Core E was drilled into a sinter debris apron $30 \mathrm{~m}$ southeast of Core $\mathrm{A}$, and $15 \mathrm{~m}$ southeast of Mound 502 itself. The core begins approximately four meters below the top of Core A, and is the deepest of the four cores, reaching $560 \mathrm{~cm}$ depth. Core E records the highest diversity of sedimentary facies and geochemical signatures, including highertemperature columnar sinters, lower-temperature mat facies, and clastic sandstone beds.

Core $\mathrm{E}$ is the only core examined to record non-hydrothermal sediments deposited prior to extensive sinter formation, appearing as sandstones below $4 \mathrm{~m}$ depth (Fig. 13). Most sandstones present are massive and are likely the result of debris flows from surrounding hillsides into valleys to the south (Fig. 1B). However, minor layers of laminated sinter occur throughout sandstone beds, indicating an influence from hydrothermal activity. The high abundance of $\mathrm{SiO}_{2}$ throughout the sandstone succession in combination with the lack of detrital quartz (Fig. 13F) indicates that this hydrothermal influence persisted throughout the sandstone deposits. Minor variations in the $\mathrm{SiO}_{2}$ concentration are most likely due to differences in the amount of silica cement.

Layers between 2.9 and $3.7 \mathrm{~m}$ depth in Core E form the most diverse assemblage of facies in any core measured in this study. Six different facies occur within $80 \mathrm{~cm}$, with no single unit exceeding ten centimeters in thickness (Fig. 2). Such disparate lithologies imply relatively rapid environmental shifts on Mound 502's outer distal apron, including hydrothermal vent sources separate from the mound's central pool. Two sedimentary cycles are noted, each shifting from subaqueous or poolside facies to outflow environments. The lower cycle (3.4-3.7 m depth) features a thin layer of small columnar sinter (Figs. 6F, 7B) overlain by tufted mat sinters and laminated sandstones. The upper cycle (2.9-3.4 m depth) contains massive and arborescent sinters overlain by mixed tufted mats and sandstones. In other cores, columnar and massive sinters typically contain elevated positive Eu anomalies indicative of extensive hydrothermal silica precipitation. However, between 2.9 and $3.7 \mathrm{~cm}$ depth in Core $\mathrm{E}$ the relative concentration of Eu is similar to that of the underlying sandstone, but increases only slightly up section (Fig. 15). By contrast, concentrations of $\mathrm{Al}_{2} \mathrm{O}_{3}$ and other elements decrease by orders of magnitude (Fig. 14). Together, petrographic-, Eu-, and $\mathrm{Al}_{2} \mathrm{O}_{3}$-data depict a location experiencing locally rapid depositional shifts, with an underlying trend of increasing hydrothermal sinter precipitation and decreasing siliciclastic input (Fig. 16).

The only section of Core E recovered between 2 and $3 \mathrm{~m}$ is a 30 centimeter section (2.2-2.5 cm depth) of palisade mat fabrics underlain by thin beds of massive sinter. The abrupt transition from massive to palisade sinters is similar to Core $\mathrm{D}$, with more detailed geochemical data sampling revealing distinct shifts in temperature and siliciclastic influence. Positive Eu anomalies in massive sinters are equivalent to core facies at $3 \mathrm{~m}$ depth (Fig. 16). In contrast, immediately overlying palisade mat sinters contain no Eu anomaly, but quickly return over the subsequent twenty centimeters. $\mathrm{Al}_{2} \mathrm{O}_{3}$ and other siliciclastic constituents are anticorrelated to relative Eu concentration, increasing sharply in lower palisade sinters and decreasing up-section (Figs. 14, 15). Geochemical trends indicate hydrothermal environments with a low siliciclastic component, succeeded by palisade mats potentially growing at $\sim 40{ }^{\circ} \mathrm{C}$ (Walter, 1976a; Campbell et al., 2015; Gong et al., 2019), though potentially persisting in higher temperatures. No change in mat architecture is associated with changes in relative Eu concentrations.

Between 1.0 and $2.0 \mathrm{~m}$ depth, Core $\mathrm{E}$ is entirely composed of particulate, massive, and arborescent sinters. Particulate and massive facies are frequently interpreted as subaqueous deposits in hightemperature pools (Walter, 1976b; Braunstein and Lowe, 2001; Lowe and Braunstein, 2003; Hinman and Walter, 2005), and Core E geochemistry supports similar conclusions. The highest positive Eu anomalies in Core E occur between 1.5 and $2.0 \mathrm{~m}$ depth, similar to values observed in sinter crusts and columnar sinters in Cores A and C (Fig. 16). As in more vent-proximal cores, positive Eu anomalies gradually decrease upsection, eventually approaching similar relative Eu ratios observed in lower Core $\mathrm{E}$ sinters. Concentrations of $\mathrm{Al}_{2} \mathrm{O}_{3}, \sum \mathrm{REE}$ and other siliciclastic proxies reach minimum values in Core $\mathrm{E}$ between 1.0 and $2.0 \mathrm{~m}$, and remain consistently low throughout dendritic and associated sinters (Figs. 14, 16). Unlike inclined sinter crusts in Core A and columnar sinter in Core C, high-temperature facies in Core $\mathrm{E}$ appear to have precipitated on flat-bottomed pools on distal aprons, separate from the elevated sinter mound (Fig. 17). Such pools are still active several meters away from Core E, supporting their potential presence during Core E deposition. The presence of arborescent sinter between particulate facies most likely represents a shift from pool deposits to outflow channels with microbial communities (Guidry and Chafetz, 2003c).

The top meter of Core E contains the thickest continuous package of microbial facies in any core examined. Palisades comprise the majority of preserved mats, with nearly identical fenestral morphologies to the upper beds of Cores C and D (Fig. 9C). The lower boundary between particulate sinters and overlying palisades is associated with an immediate loss of the positive Eu anomaly, followed by fluctuations around the average for clastic deposition around Mound 502 (Fig. 16). Unlike Cores $\mathrm{C}$ and $\mathrm{D}$, palisades in Core E contain distinct interstitial layers of tufted microbial sinters. Tufted sinters are typically assigned to higher-temperature communities $\left(45-60{ }^{\circ} \mathrm{C}\right)$ than palisade mats $\left(<45{ }^{\circ} \mathrm{C}\right)$, based on 
morphologies of modern hot spring communities (Walter, 1976a; Campbell et al., 2001; Lynne and Campbell, 2003; Fernandez-Turiel et al., 2005). No clear difference in REE signatures exists between tufted and palisade mat sinters in El Tatio cores, most likely due to the entrapment of siliciclastic material on sticky microbial surfaces.

The diversity of facies observed in Core E resembles previous stratigraphic studies from distal sinter deposits around the world (Trewin, 1993; Walter et al., 1996, 1998; Jones et al., 1998; Campbell et al., 2001, 2020; Guidry and Chafetz, 2003b; Lynne et al., 2008). Palisade and tufted microbial mats are ubiquitous facies in cooler environments (Walter et al., 1996, 1998; Jones et al., 1998; Campbell et al., 2001, 2020), while branching arborescent textures are described less frequently (Walter et al., 1996, 1998; Campbell et al., 2001). The frequent interbedding between microbial facies and more massive deposits in Core E (1-2, 3-3.5 m depth) is also a common feature of distal sinter stratigraphy (Walter et al., 1996; Campbell et al., 2001; Lynne et al., 2008). In contrast, Core E lacks extensive preservation of metazoan communities such as plants or diatoms, which are often observed in distal sinters (Trewin, 1993; Walter et al., 1996, 1998; Campbell et al., 2001, 2020; Guidry and Chafetz, 2003b). While the climate at El Tatio is more extreme than many other sinter localities, scattered areas with plant life are present. However, areas selected for coring in Mound 502 lack extensive vegetation, and the absence of plant remains suggests similar ecological conditions during sinter deposition. Core stratigraphy from Mound 502 therefore presents a closer environmental analogue to early sinters on Earth or Mars than other distal deposits.

\subsection{Sinter ages}

Five ${ }^{14} \mathrm{C}$ ages were measured from Cores $\mathrm{C}$ and $\mathrm{E}$ (Table 1, Fig. 2), ranging between 6907 and 13,337 y. cal. BP. Core E contains a consistent progression from 13,337 to $10,028 \mathrm{y}$. cal. BP, underlain by an age of 6907 y. cal. BP at $347 \mathrm{~cm}$ depth (Table 1, Fig. 2). Similar irregularities have been noted in previous sinter cores (Lynne et al., 2008; Lowenstern et al., 2016), and have several potential explanations. The presence of younger dates below a series of consistently older data points can be explained by transport of younger material into deeper sediments by subsurface infiltration through fractures and pores (Lynne et al., 2008; Lynne, 2012). In support of this hypothesis, various core depths contain fracture zones associated with secondary mineral phases, including massive sandstones deeper in Core E (Fig. 13B). While no specific fractures are apparent at $347 \mathrm{~cm}$, the sinter bed is fairly porous, and is ten centimeters below a massive, altered sinter (Fig. 2). We propose that younger material permeated through fissures and pores in older sinters via secondary fluid flow, producing an anomalous radiocarbon date thousands of years younger than three succeeding deposits.

The four remaining ${ }^{14} \mathrm{C}$ ages (one in Core $\mathrm{C}$, three in Core $\mathrm{E}$ ) record more than three thousand years of sinter deposition in Mound 502 (Figs. 2, 17, Table 1). A transition from clastic sandstones to siliceous sinter occurred more than $13,337 \mathrm{y}$. cal. BP in distal debris aprons (Core E, $310.5 \mathrm{~cm}$ depth). Between 13,337 and 10,931 y. cal. BP (Core E, $33 \mathrm{~cm}$ depth), Core E experienced shifts between various sinter facies, including microbial mats and detrital-poor vent proximal zones (Figs. 2, 17). After 10,931 y. cal. BP, palisade mat sinters dominate deposition in Cores $\mathrm{C}$ and $\mathrm{E}$ (and presumably D) until at least 10,028 y. cal. BP (Core E, $6 \mathrm{~cm}$ depth). The ages from Mound 502 supports previous timelines of hydrothermal activity in El Tatio, which initiated at least $27 \mathrm{ka}$, and persisted until the present day without major hiatuses (Slagter et al., 2019; Munoz-Saez et al., 2020).

The ${ }^{14} \mathrm{C}$ ages from Mound 502 cores are thousands of years older than surficial deposits from the same location (Slagter et al., 2019). Four data points collected on a transect between Cores $A$ and $C$ (Fig. 17B, C) record a period of deposition between 2241 and $197 \mathrm{y}$. cal. BP (Slagter et al., 2019). The age difference between the two datasets is interpreted as a depositional hiatus separating two phases of sinter deposition. The first phase formed the majority of deposits in Cores $C$ and E between $\sim 14,000$ and 10,000 y. cal. BP. After $\sim 7000$ years, surficial hydrothermal activity resumed, forming surficial sinters between 2500 and 200 y. cal. BP (Slagter et al., 2019). Depositional hiatuses of similar length have previously been reported from hydrothermal zones in Yellowstone and New Zealand (Foley, 2006; Drake et al., 2014; Hurwitz and Lowenstern, 2014), and are most likely due to changes in subsurface hydrothermal systems.

The age of Core $A$ remains uncertain relative to other cores. One unconformity exists in Core A at $35 \mathrm{~cm}$ depth, indicating a prolonged period of hydrothermal activity, followed by a hiatus and minor subsequent sinter deposition. The current set of ${ }^{14} \mathrm{C}$ ages from surficial and core samples presents two potential timelines (Fig. 17A). In one scenario, most of Core A was deposited during the initial period of hydrothermal activity, forming an elevated sinter mound more than $10,000 \mathrm{y}$. cal. BP followed by a resurgence of activity after $2000 \mathrm{y}$. cal. BP. Alternatively, the inner mound and Core A could have formed after 2000 y. cal. BP, with Cores C, D, and E representing relatively lowrelief mound and outflow deposits (Fig. 17A). In either case, depositional interpretations for all cores remain the same, with timing more well-constrained between more distal depositional facies.

\section{Conclusions}

The four cores examined provide the first complete stratigraphic transect of a recent sinter mound from vent to outflow. Lateral trends of hydrothermal deposits record detailed transitions in chemistry, sedimentology and biology over broad areas, while vertical profiles provide similar records for local environments over geologic time. Initial depositional interpretations from sedimentology and petrography match geochemical data from the same facies. Combining all approaches within a single location provides a detailed environmental history that includes the initiation, accretion, and eventual cessation of sinter deposition within a single mound.

Hydrothermal activity started in the western margins of El Tatio's upper basin prior to $13,337 \mathrm{y}$. cal. BP. Sinter deposits formed on underlying glacial sandstones, intermittently at first, then forming a wide diversity of biogenic and abiogenic textures. Deposits closest to the original hydrothermal vent are dominated by subaqueous precipitation on the steep margins of a high-temperature pool. Several meters away, extensive columnar sinter formed on outer pool margins experiencing alternate periods of pool overflow and subaerial evaporation. Less extensive pools with subaqueous and columnar facies also formed in distal aprons. Microfossils are rare to absent in high-temperature facies $(>70$ ${ }^{\circ} \mathrm{C}$ ), with silica precipitation most likely driven by physico-chemical factors such as silica concentrations, cooling, and evaporation. On the other hand, extensive microbial deposits are present in cooler, distal environments with more siliciclastic input. Palisade, tufted, and arborescent sinters indicate the presence of multiple distinct microbial communities, potentially fluctuating with water temperature and flow dynamics. Mat deposits and detrital-rich facies eventually replace hightemperature sinters in the upper sections of all cores, signifying cooling and eventual termination of local deposition no more than 10,232 y. cal. $\mathrm{BP}$. In other areas of the same mound, hydrothermal activity persisted for several thousand years (Slagter et al., 2019).

As seen within the El Tatio cores, sinter stratigraphy is complex, and varies both laterally and vertically on relatively fine scales. The deposits examined represent only one type of hydrothermal outflow, a topographically-elevated boiling, surging pool. Similar coring studies performed on extinct structures such as fountain geysers and lowrelief, non-surging pools are likely to reveal different facies patterns. Further sinter stratigraphy, especially in the harsh environmental conditions of El Tatio, also provides a comparison for Archean and Martian sinters and their biosignature potential. Microfossils are present in all four cores, but are far more prevalent and well-preserved in outflow and distal deposits. Many vent-proximal sinters are ambiguously 
biogenic, but the sparse remains of microbial filaments indicate a biological presence, and such deposits should not be overlooked in future stratigraphic studies.

\section{Declaration of competing interest}

The authors declare that they have no known competing financial interests or personal relationships that could have appeared to influence the work reported in this paper.

\section{Acknowledgements}

This research was funded by the European Research Council under the European Union's Horizon 2020 Research and Innovation Program (Grant Agreement \#646894) to M.V.Z. The authors would like to thank Prisca Grandin for geochemical laboratory assistance (IUEM, Brest, France), Jean-Pierre Oldra (IUEM, Brest, France) and the Thin Section Lab (Toul, France), for petrographic preparation, Stefan Borensztajn (IPGP, Paris, France) and the Toconce and Caspana communities managing the El Tatio Geyser Field tourism and outreach for permission to sample in the area.

\section{Appendix A. Supplementary}

Supplementary data to this article can be found online at https://doi. org/10.1016/j.sedgeo.2020.105726.

\section{References}

Bargar, K.E., Beeson, M.H., 1981. Hydrothermal alteration in research drill hole Y-2, Lower Geyser basin, Yellowstone National Park, Wyoming. Am. Mineral. 66, 473-490.

Berelson, W.M., Corsetti, F.A., Pepe-Ranney, C., Hammond, D.E., Beaumont, W., Spear, J.R., 2011. Hot spring siliceous stromatolites from Yellowstone National Park: assessing growth rate and laminae formation. Geobiology 9, 411-424. https://doi.org/ 10.1111/j.1472-4669.2011.00288.x.

Bosak, T., Liang, B., Sim, M.S., Petroff, A.P., 2009. Morphological record of oxygenic photosynthesis in conical stromatolites. Proc. Natl. Acad. Sci. 106, 10939-10943. https:// doi.org/10.1073/pnas.0900885106.

Bosak, T., Bush, J.W.M., Flynn, M.R., Liang, B., Ono, S., Petroff, A.P., Sim, M.S., 2010. Formation and stability of oxygen-rich bubbles that shape photosynthetic mats. Geobiology 8, 45-55. https://doi.org/10.1111/j.1472-4669.2009.00227.x.

Bosak, T., Liang, B., Wu, T.D., Templer, S.P., Evans, A., Vali, H., Guerquin-Kern, J.L., KlepacCeraj, V., Sim, M.S., Mui, J., 2012. Cyanobacterial diversity and activity in modern conical microbialites. Geobiology. https://doi.org/10.1111/j.1472-4669.2012.00334.x.

Boudreau, A.E., Lynne, B.Y., 2012. The growth of siliceous sinter deposits around hightemperature eruptive hot springs. J. Volcanol. Geotherm. Res. 247-248, 1-8. https:// doi.org/10.1016/j.jvolgeores.2012.07.008

Bradley, J.A., Daille, L.K., Trivedi, C.B., Bojanowski, C.L., Stamps, B.W., Stevenson, B.S., Nunn, H.S., Johnson, H.A., Loyd, S.J., Berelson, W.M., Corsetti, F.A., Spear, J.R., 2017. Carbonate-rich dendrolitic cones: insights into a modern analog for incipient microbialite formation, Little Hot Creek, Long Valley Caldera, California. npj Biofilms Microbiomes 3. https://doi.org/10.1038/s41522-017-0041-2.

Braunstein, D., Lowe, D.R., 2001. Relationship between spring and geyser activity and the deposition and morphology of high temperature (> 73 C) siliceous sinter, Yellowstone National Park, Wyoming, USA. J. Sediment. Res. 71, 747-763.

Cady, S.L., Farmer, J.D., 1996. Fossilization processes in siliceous thermal springs: trends in preservation along thermal gradients. CIBA Found. Symp., 150-173 https://doi.org/ 10.1002/9780470514986.ch9.

Calvert, S.E., 1976. The mineralogy and geochemistry of near-shore sediments. Chemical Oceanography, pp. 187-280 https://doi.org/10.1016/b978-0-12-588606-2.50014-x.

Campbell, K.A., Sannazzaro, K., Rodgers, K.A., Herdianita, N.R., Browne, P.R.L., 2001. Sedimentary facies and mineralogy of the Late Pleistocene Umukuri Silica Sinter, Taupo Volcanic Zone, New Zealand. J. Sediment. Res. 71, 727-746. https://doi.org/10.1306/ 2dc40964-0e47-11d7-8643000102c1865d.

Campbell, K.A., Lynne, B.Y., Handley, K.M., Jordan, S., Farmer, J.D., Guido, D.M., Foucher, F., Turner, S., Perry, R.S., 2015. Tracing biosignature preservation of geothermally silicified microbial textures into the geological record. Astrobiology. https://doi.org/ 10.1089/ast.2015.1307.

Campbell, K.A., Nicholson, K., Lynne, B.Y., Browne, P.R.L., 2020. 3D Anatomy of a 60-year-old siliceous hot spring deposit at Hipaua-Waihi-Tokaanu geothermal field, Taupo Volcanic Zone, New Zealand. Sediment. Geol. https://doi.org/10.1016/j.sedgeo.2020.105652.

Cockell, C.S., 2000. Ultraviolet radiation and the photobiology of earth's early oceans. Orig. Life Evol. Biosph. 30, 467-500. https://doi.org/10.1023/A:1006765405786.

Cortecci, G., Boschetti, T., Mussi, M., Lameli, C.H., Mucchino, C., Barbieri, M., 2005. New chemical and original isotopic data on waters from El Tatio geothermal field, northern Chile. Geochem. J. 39 (6), 547-571.

Cotten, J., Le Dez, A., Bau, M., Caroff, M., Maury, R., Dulski, P., Fourcade, S., Bohn, M., Brousse, R., 1995. Origin of rare-earth element and yttrium enrichments in subaerial exposed basalts: evidence from French Polynesia. Chem. Geol. 119, 115-138. https:// doi.org/10.1016/0009-2541(94)00102-E.

De Silva, S.L., 1989. Altiplano-Puna volcanic complex of the Central Andes. Geology 17 1102-1106. https://doi.org/10.1130/0091-7613(1989)017<1102:APVCOT>2.3.CO;2.

De Silva, S.L., Self, S., Francis, P.W., Drake, R.E., C., Ramirez R., 1994. Effusive silicic volcanism in the Central Andes: the Chao dacite and other young lavas of the AltiplanoPuna volcanic complex. J. Geophys. Res. 99. https://doi.org/10.1029/94jb00652.

DGA Direccion general de aguas de chile, 2017. Información Oficial Hidrometeorológica y de Calidad de Aguas en Línea. https://dga.mop.gob.cl/. (Accessed March 2017).

Djokic, T., Van Kranendonk, M.J., Campbel, K.A., Walter, M.R., Ward, C.R., 2017. Earliest signs of life on land preserved in ca. $3.5 \mathrm{Ga}$ hot spring deposits. Nat. Commun. 8. https://doi.org/10.1038/ncomms15263.

Drake, B.D., Campbell, K.A., Rowland, J.V., Guido, D.M., Browne, P.R., Rae, A., 2014. Evolution of a dynamic paleo-hydrothermal system at Mangatete, Taupo Volcanic Zone, New Zealand. J. Volcanol. Geotherm. Res. 282, 19-35. https://doi.org/10.1016/j. jvolgeores.2014.06.010.

Feng, J.L., Zhao, Z.H., Chen, F., Hu, H.P., 2014. Rare earth elements in sinters from the geothermal waters (hot springs) on the Tibetan Plateau, China. J. Volcanol. Geotherm. Res. 287, 1-11. https://doi.org/10.1016/j.jvolgeores.2014.09.009.

Fernandez-Turiel, J.L., Garcia-Valles, M., Gimeno-Torrente, D., Saavedra-Alonso, J., Martinez-Manent, S., 2005. The hot spring and geyser sinters of El Tatio, northern Chile. Sediment. Geol. 180, 125-147. https://doi.org/10.1016/j.sedgeo.2005.07.005.

Foley, D., 2006. Dating castle geyser: preliminary results and broad speculations on the geologic development of geysers and hydrothermal systems in Yellowstone national park, Wyoming, USA. Trans. Geotherm. Res. Council 30, 413-417.

Frantz, C.M., Petryshyn, V.A., Corsetti, F.A., 2015. Grain trapping by filamentous cyanobacterial and algal mats: implications for stromatolite microfabrics through time. Geobiology 13, 409-423. https://doi.org/10.1111/gbi.12145.

Gebelein, C.D., 1969. Distribution, morphology, and accretion rate of recent subtidal algal stromatolites, Bermuda. J. Sediment. Petrol. https://doi.org/10.1306/74D71BE0-2B2111D7-8648000102C1865D.

Giggenbach, W.F., 1978. The isotopic composition of waters from the El Tatio geotherma field, Northern Chile. Geochim. Cosmochim. Acta 42, 979-988. https://doi.org/ 10.1016/0016-7037(78)90287-9.

Glennon, J.A., Pfaff, R.M., 2003. The Extraordinary Thermal Activity of El Tatio Geyser Field Antofagasta Region, Chile. 8. GOSA Trans, pp. 31-78.

Gong, J., Myers, K.D., Munoz-Saez, C., Homann, M., Rouillard, J., Wirth, R., Schreiber, A., van Zuilen, M.A., 2019. Formation and preservation of microbial palisade fabric in silica deposits from El Tatio, Chile. Astrobiology 20, 1-25. https://doi.org/10.1089/ ast.2019.2025.

Govindaraju, K., 1995. 1995 working values with confidence limits for twenty-six CRPG ANRT AND IWG-GIT geostandards. Geostand. Newslett. 19, 1-32. https://doi.org/ 10.1111/j.1751-908X.1995.tb00164.X.

Guidry, S.A., Chafetz, H.S., 2003a. Anatomy of siliceous hot springs: examples from Yellowstone National Park, Wyoming, USA. Sediment. Geol. 157, 71-106. https://doi org/10.1016/S0037-0738(02)00195-1.

Guidry, S.A., Chafetz, H.S., 2003b. Depositional facies and diagenetic alteration in a relict siliceous hot-spring accumulation: examples from Yellowstone National Park, U.S.A. J. Sediment. Res. 73, 806-823. https://doi.org/10.1306/022803730806.

Guidry, S.A., Chafetz, H.S., 2003c. Siliceous shrubs in hot springs from Yellowstone National Park, Wyoming, U.S.A. Can. J. Earth Sci. 40, 1571-1583. https://doi.org/ 10.1139/e03-069.

Handley, K.M., Campbell, K.A., 2011. Character, Analysis, and Preservation of Biogenicity in Terrestrial Siliceous Stromatolites from Geothermal Settings. https://doi.org/ 10.1007/978-94-007-0397-1_16.

Handley, K.M., Campbell, K.A., Mountain, B.W., Browne, P.R.L., 2005. Abiotic-biotic controls on the origin and development of spicular sinter: in situ growth experiments, Champagne Pool, Waiotapu, New Zealand. Geobiology 3, 93-114. https://doi.org/ 10.1111/j.1472-4669.2005.00046.x.

Handley, K.M., Turner, S.J., Campbell, K.A., Mountain, B.W., 2008. Silicifying biofilm exopolymers on a hot-spring microstromatolite: templating nanometer-thick laminae. Astrobiology. https://doi.org/10.1089/ast.2007.0172.

Healy, J., Hochstein, M.P., 1973. Horizontal flow in hydrothermal systems. J. Hydrol. NZ 71-82.

Hinman, N.W., Walter, M.R., 2005. Textural preservation in siliceous hot spring deposits during early diagenesis: examples from Yellowstone National Park and Nevada, U.S a. J. Sediment. Res. 75, 200-215. https://doi.org/10.2110/jsr.2005.016.

Hogg, A.G., Hua, Q., Blackwell, P.G., Niu, M., Buck, C.E., Guilderson, T.P., Heaton, T.J., Palmer J.G., Reimer, P.J., Reimer, R.W., Turney, C.S.M., Zimmerman, S.R.H., 2013. SHCal13 southern hemisphere calibration, 0-50,000 years cal BP. Radiocarbon 55, 1889-1903. https://doi.org/10.2458/azu_js_rc.55.16783.

Hurwitz, S., Lowenstern, J.B., 2014. Dynamics of the Yellowstone hydrothermal system. Rev. Geophys. 52 (3), 375-411. https://doi.org/10.1002/2014RG000452.

Jones, B., Renaut, R.W., 1996. Influence of thermophilic bacteria on calcite and silica precipitation in hot springs with water temperatures above $90^{\circ} \mathrm{C}$ : evidence from Kenya and New Zealand. Can. J. Earth Sci. https://doi.org/10.1139/e96-008.

Jones, B., Renaut, R.W., 1997. Formation of silica oncoids around geysers and hot springs at El Tatio, northern Chile. Sedimentology 44, 287-304. https://doi.org/10.1111/ j.1365-3091.1997.tb01525.x.

Jones, B., Renaut, R.W., 2003. Petrography and genesis of spicular and columnar geyserite from the Whakarewarewa and Orakeikorako geothermal areas, North Island, New Zealand. Can. J. Earth Sci. 40, 1585-1610. https://doi.org/10.1139/e03-062.

Jones, B., Renaut, R.W., 2006. Growth of siliceous spicules in acidic hot springs, Waiotapu Geothermal Area, North Island, New Zealand. Palaios 21, 406-423. https://doi.org/ 10.2110/palo.2006.p06-026. 
Jones, B., Renaut, R.W., Rosen, M.R., 1997. Biogenicity of silica precipitation around geysers and hot-spring vents, North Island, New Zealand. J. Sediment. Res. 67, 88-104. https://doi.org/10.1306/d42684ff-2b26-11d7-8648000102c1865d.

Jones, B., Renaut, R.W., Rosen, M.R., 1998. Microbial biofacies in hot-spring sinters; model based on Ohaaki Pool, North Island, New Zealand. J. Sediment. Res. 68, 413-434. https://doi.org/10.2110/jsr.68.413.

Jones, B., Konhauser, K.O., Renaut, R., Wheeler, R., 2004. Microbe silicification in Iodine Pool, Waimangu geothermal area, North Island, New Zealand: Implications for recognition and identification of ancient silicified microbes. J. Geol. Soc. Lond. 161, 983-993.

Jones, B., Renaut, R.W., Konhauser, K.O., 2005. Genesis of large siliceous stromatolites at Frying Pan Lake, Waimangu geothermal field, North Island, New Zealand. Sedimentology 52, 1229-1252. https://doi.org/10.1111/j.1365-3091.2005.00739.x.

Konhauser, K.O., Ferris, F.G., 1996. Diversity of iron and silica precipitation by microbial biofilms in hydrothermal waters, Iceland: implications for Precambrian iron formations. Geology 24, 323-326.

Konhauser, K.O., Phoenix, V.R., Bottrell, S.H., Adams, D.G., Head, I.M., 2001. Microbial-silica interactions in Icelandic hot spring sinter: possible analogues for some Precambrian siliceous stromatolites. Sedimentology 48, 415-433. https://doi.org/10.1046/j.13653091.2001.00372.x.

Konhauser, K.O., Jones, B., Phoenix, V.R., Ferris, F.G., Renaut, R.W., 2004. The microbial role in hot spring silicification. AMBIO J. Hum. Environ. 33 (8), 552-558. https://doi.org/ 10.1579/0044-7447-33.8.552.

Konhauser, K.O., Jones, B., Reysenbach, A.L., Renaut, R.W., 2003. Hot spring sinters: keys to understanding Earth's earliest life forms. Can. J. Earth Sci. 40, 1713-1724. https://doi. org/10.1139/e03-059.

Lahsen, A., Trujillo, P., 1976. The geothermal field of El Tatio, Chile. Proceeding, Second United Nations Symposium on the Development and Use of Geothermal Resources, San Francisco. Vol. 1, pp. 170-177.

Landrum, J.T., Bennett, P.C., Engel, A.S., Alsina, M.A., Pastén, P.A., Milliken, K., 2009 Partitioning geochemistry of arsenic and antimony, El Tatio Geyser Field, Chile. Appl. Geochem. https://doi.org/10.1016/j.apgeochem.2008.12.024.

Lau, E., Nash, C.Z., Vogler, D.R., Cullings, K.W., 2005. Molecular diversity of cyanobacteria inhabiting coniform structures and sorrounding mat in a Yellowstone hot spring. Astrobiology 5, 83-92. https://doi.org/10.1089/ast.2005.5.83.

Leidig, M., Zandt, G., 2003. Modeling of highly anisotropic crust and application to the Altiplano-Puna volcanic complex of the central Andes. J. Geophys. Res. Solid Earth 108, ESE 5-1-ESE 5-15. https://doi.org/10.1029/2001jb000649.

Lewis, A.J., Palmer, M.R., Sturchio, N.C., Kemp, A.J., 1997. The rare earth element geochemistry of acid-sulphate and acid-sulphate-chloride geothermal systems from Yellowstone National Park, Wyoming, USA. Geochim. Cosmochim. Acta 61, 695-706. https://doi.org/10.1016/S0016-7037(96)00384-5.

Lowe, D.R., Braunstein, D., 2003. Microstructure of high-temperature $\left(>73^{\circ} \mathrm{C}\right)$ siliceous sinter deposited around hot springs and geysers, Yellowstone National Park: the role of biological and abiological processes in sedimentation. Can. J. Earth Sci. 40, 1611-1642. https://doi.org/10.1139/e03-066.

Lowenstern, J.B., Hurwitz, S., McGeehin, J.P., 2016. Radiocarbon dating of silica sinter deposits in shallow drill cores from the Upper Geyser Basin, Yellowstone National Park. J. Volcanol. Geotherm. Res. 310, 132-136. https://doi.org/10.1016/j.jvolgeores.2015.12.005

Lynne, B.Y., 2012. Mapping vent to distal-apron hot spring paleo-flow pathways using siliceous sinter architecture. Geothermics 43, 3-24. https://doi.org/10.1016/j. geothermics.2012.01.004.

Lynne, B.Y., Campbell, K.A., 2003. Diagenetic transformations (opal-a to quartz) of lowand mid-temperature microbial textures in siliceous hot-spring deposits, Taupo Volcanic Zone, New Zealand. Can. J. Earth Sci. 40, 1679-1696. https://doi.org/10.1139/ e03-064.

Lynne, B.Y., Campbell, K.A., Moore, J., Browne, P.R.L., 2008. Origin and evolution of the Steamboat Springs siliceous sinter deposit, Nevada, U.S.A. Sediment. Geol. 210 111-131. https://doi.org/10.1016/j.sedgeo.2008.07.006.

Mata, S.A., Harwood, C.L., Corsetti, F.A., Stork, N.J., Eilers, K., Berelson, W.M., Spear, J.R 2012. Influence of gas production and filament orientation on stromatolite microfabric. Palaios 27, 206-219. https://doi.org/10.2110/palo.2011.p11-088r.

Michard, A., 1989. Rare earth element systematics in hydrothermal fluids. Geochim. Cosmochim. Acta 53, 745-750. https://doi.org/10.1016/0016-7037(89)90017-3.

Mountain, B.W., Benning, L.G., Boerema, J.A., 2003. Experimental studies on New Zealand hot spring sinters: rates of growth and textural development. Can. J. Earth Sci. 40 1643-1667. https://doi.org/10.1139/e03-068.

Munoz-Saez, C., Manga, M., Hurwitz, S., Rudolph, M.L., Namiki, A., Wang, C.Y., 2015. Dynamics within geyser conduits, and sensitivity to environmental perturbations: insights from a periodic geyser in the El Tatio geyser field, Atacama Desert, Chile. J. Volcanol. Geotherm. Res. 292, 41-55. https://doi.org/10.1016/j.jvolgeores.2015.01.002.

Munoz-Saez, C., Saltiel, S., Manga, M., Nguyen, C., Gonnermann, H., 2016. Physical and hydraulic properties of modern sinter deposits: El Tatio, Atacama. J. Volcanol. Geotherm. Res. https://doi.org/10.1016/j.jvolgeores.2016.06.026.

Munoz-Saez, C., Manga, M., Hurwitz, S., 2018. Hydrothermal discharge from the El Tatio basin, Atacama, Chile. J. Volcanol. Geotherm. Res. 361, 25-35. https://doi.org/ 10.1016/j.jvolgeores.2018.07.007.

Munoz-Saez, C., Manga, M., Hurwitz, S., Slagter, S., Churchill, D.M., Reich, M., Damby, D., Morata, D., 2020. Radiocarbon dating of silica sinter and postglacial hydrothermal activity in the El Tatio geyser field. Geophys. Res. Lett. 47, e2020GL087908.

Nicolau, C., Reich, M., Lynne, B., 2014. Physico-chemical and environmental controls on siliceous sinter formation at the high-altitude El Tatio geothermal field, Chile. J. Volcanol. Geotherm. Res. 282, 60-76. https://doi.org/10.1016/j.jvolgeores.2014.06.012.

Pepe-Ranney, C., Berelson, W.M., Corsetti, F.A., Treants, M., Spear, J.R., 2012. Cyanobacterial construction of hot spring siliceous stromatolites in Yellowstone National Park. Environ. Microbiol. 14, 1182-1197. https://doi.org/10.1111/j.1462-2920.2012.02698.x.
Phoenix, V.R., Bennett, P.C., Engel, A.S., Tyler, S.W., Ferris, F.G., 2006. Chilean high-altitude hot-spring sinters: a model system for UV screening mechanisms by early Precambrian cyanobacteria. Geobiology 4, 15-28. https://doi.org/10.1111/j.14724669.2006.00063.x

Reyes, K., Gonzalez, N.I., Stewart, J., Ospino, F., Nguyen, D., Cho, D.T., Ghahremani, N., Spear, J.R., Johnson, H.A., 2013. Surface orientation affects the direction of cone growth by leptolyngbya sp. Strain C1, a likely architect of coniform structures octopus spring (Yellowstone National Park). Appl. Environ. Microbiol. 79, 1302-1308. https:// doi.org/10.1128/AEM.03008-12.

Riding, R., 2000. Microbial carbonates: the geological record of calcified bacterial-algal mats and biofilms. Sedimentology 47, 179-214. https://doi.org/10.1046/j.13653091.2000.00003.x.

Rimstidt, J.D., Cole, D.R., 1983. Geothermal mineralization I: the mechanism of formation of the Beowawe, Nevada, siliceous sinter deposit. Am. J. Sci. https://doi.org/10.2475/ ajs.283.8.861.

Ruff, S.W., Farmer, J.D., 2016. Silica deposits on Mars with features resembling hot spring biosignatures at El Tatio in Chile. Nat. Commun. 7. https://doi.org/10.1038/ ncomms13554.

Ruff, S.W., Campbell, K.A., Van Kranendonk, M.J., Rice, M.S., Farmer, J.D., 2020. The case for ancient hot springs in Gusev Crater, Mars. Astrobiology 20, 475-499. https://doi.org/ 10.1089/ast.2019.2044.

Sanchez-Garcia, L., Fernandez-Martinez, M.A., García-Villadangos, M., Blanco, Y., Cady, S.L. Hinman, N., Bowden, M.E., Pointing, S.B., Lee, K.C., Warren-Rhodes, K., Lacap-Bugler, Cabrol, N.A., Parro, V., Carrizo, D., 2019. Microbial biomarker transition in high-altitude sinter mounds from El Tatio (Chile) through different stages of hydrothermal activity. Front. Microbiol. https://doi.org/10.3389/fmicb.2018.03350.

Sanchez-Yanez, C., Reich, M., Leisen, M., Morata, D., Barra, F., 2017. Geochemistry of metals and metalloids in siliceous sinter deposits: Implications for elemental partitioning into silica phases. Appl. Geochem. https://doi.org/10.1016/j.apgeochem.2017.03.008.

Schultze-Lam, S., Ferris, F.G., Konhauser, K.O., Wiese, R.G., 1995. In situ silicification of an Icelandic hot spring microbial mat: implications for microfossil formation. Can. J. Earth Sci. 32, 2021-2026. https://doi.org/10.1139/e95-155.

Slagter, S., Reich, M., Munoz-Saez, C., Southon, J., Morata, D., Barra, F., Gong, J., Skok, J.R., 2019. Environmental controls on silica sinter formation revealed by radiocarbon dating. Geology. 47, pp. 1-5. https://doi.org/10.1130/G45859.1.

Som, S.M., Catling, D.C., Harnmeijer, J.P., Polivka, P.M., Buick, R., 2012. Air density 2.7 billion years ago limited to less than twice modern levels by fossil raindrop imprints. Nature 484, 359-362. https://doi.org/10.1038/nature10890.

Som, S.M., Buick, R., Hagadorn, J.W., Blake, T.S., Perreault, J.M., Harnmeijer, J.P., Catling, D. C., 2016. Earth's air pressure 2.7 billion years ago constrained to less than half of modern levels. Nat. Geosci. 9, 448-451. https://doi.org/10.1038/ngeo2713.

Sriaporn, C., Campbell, K.A., Millan, M., Ruff, S.W., Van Kranendonk, M.J., Handley, K.M., 2020. Stromatolitic digitate sinters form under wide-ranging physicochemical conditions with diverse hot spring microbial communitie. Geobiology 00,1-22. https://doi. org/10.1111/gbi.12395.

Stuiver, M., Polach, H.A., 1977. Discussion Reporting of ${ }^{14} \mathrm{C}$ Data. Radiocarbon 19 (3), 355-363. https://doi.org/10.1017/S003382220000367.

Tassi, F., Martinez, C., Vaselli, O., Capaccioni, B., Viramonte, J., 2005. Light hydrocarbons as redox and temperature indicators in the geothermal field of El Tatio (northern Chile). Appl. Geochem. 20, 2049-2062. https://doi.org/10.1016/j.apgeochem.2005.07.013.

Tassi, F., Aguilera, F., Darrah, T., Vaselli, O., Capaccioni, B., Poreda, R.J., Delgado Huertas, A. 2010. Fluid geochemistry of hydrothermal systems in the Arica-Parinacota, Tarapacá and Antofagasta regions (northern Chile). J. Volcanol. Geotherm. Res. 192, 1-15.

Tebbutt, G.E., Conley, C.D., Boyd, D.W., 1965. Lithogenesis of a distinctive carbonate rock fabric. Rocky Mt. Geol. 4 (1), 1-13.

Trewin, N.H., 1993. Depositional environment and preservation of biota in the lower Devonian hot-springs of Rhynie, Aberdeenshire, Scotland. Trans. R. Soc. Edinb. Earth Sci. 84, 433-442. https://doi.org/10.1017/S0263593300006234.

Tribovillard, N., Algeo, T.J., Lyons, T., Riboulleau, A., 2006. Trace metals as paleoredox and paleoproductivity proxies: an update. Chem. Geol. 232, 12-32. https://doi.org/ 10.1016/j.chemgeo.2006.02.012.

Trujillo, P., 1969. Estudio para el desarollo geotérmico en el norte de ChileManifestaciones termales de El Tatio. CORFO Project Report, Provincia de Antofagasta.

Walter, M.R., 1972. A hot spring analog for the depositional environment of Precambrian iron formations of the Lake Superior Region. Econ. Geol. 67 (7), 965-972.

Walter, M.R., 1976a. Chapter 8.8 Hot-Spring Sediments in Yellowstone National Park. Dev. Sedimentol. 20, 489-498. https://doi.org/10.1016/S0070-4571(08)71153-1.

Walter, M.R., 1976b. Chapter 3.3 geyserites of Yellowstone National Park: an example of abiogenic "Stromatolites.". Dev. Sedimentol. 20, 87-112.

Walter, M.R., Des Marais, D., Farmer, J.D., Hinman, N.W., 1996. Lithofacies and biofacies of mid-paleozoic thermal spring deposits in the Drummond Basin, Queensland, Australia. Palaios 11, 497. https://doi.org/10.2307/3515187.

Walter, M.R., McLoughlin, S., Drinnan, A.N., Farmer, J.D., 1998. Palaeontology of Devonian thermal spring deposits, Drummond Basin, Australia. Alcheringa 22, 285-314. https://doi.org/10.1080/03115519808619328.

Ward, K.M., Zandt, G., Beck, S.L., Christensen, D.H., McFarlin, H., 2014. Seismic imaging of the magmatic underpinnings beneath the Altiplano-Puna volcanic complex from the joint inversion of surface wave dispersion and receiver functions. Earth Planet. Sci. Lett. 404, 43-53.

Watts-Henwood, N., Campbell, K.A., Lynne, B.Y., Guido, D.M., Rowland, J.V., Browne, P.R.L., 2017. Snapshot of hot-spring sinter at Geyser Valley, Wairakei, New Zealand, following anthropogenic drawdown of the geothermal reservoir. Geothermics. https://doi. org/10.1016/j.geothermics.2017.03.002.

Zeil, W., 1959. Junger Vulkanismus in der Hochkordillere der Provinz Antofagasta (Chile). Geol. Rundsch. 48, 218-232. https://doi.org/10.1007/BF01801827. 